\title{
Agriculture and Rural Development Western Afghanistan
}

\section{Strategy Development Workshop}

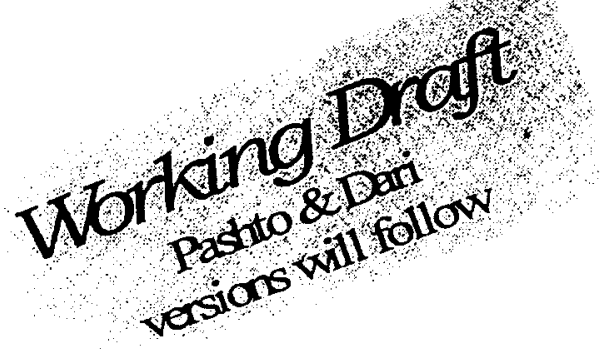

$17^{\text {th }}-21^{\text {st }}$ June, 2003

Herat

Facilitation \& Report by Mahmood Hemani

For copies, comments, feedback, and queries please contact FAO Program Management Unit, either of following Mr. Manfred Staab, Programme Manager manfred.staab@af.fao.org Ph: 070 - 288165

Mr. Abdul Rahim, Senior National Programme Officer abdul.rahim@af.fao.org Ph: 070 - 299033

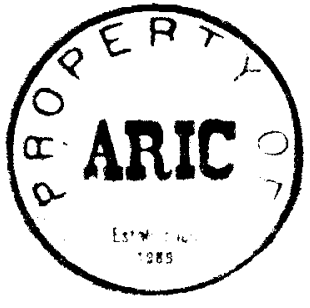

Jointly Organised by

UNITED NATIONS FOOD \& AGRICULTURE ORGANIZATION (UN FAO Afghanistan Programme)

Ministry of Agriculture and Animal Husbandry Ministry of Irrigation, Water Resources and Environment Ministry of Rural Rehabilitation and Development Government of Afghanistan 


\section{About this document}

This document presents the outcome of one workshop as part of a cycle of six workshops undertaken in all regions of Afghanistan (Kandahar, Herat, Mazar, Jalalabad, Kabul (2x) with approximately 350 participants in total. With a few exceptions all of the participants were experienced Afghan professionals and officers of the Government.

The workshops took place between July and September 2003 and were jointly organized and implemented by the area offices of FAO and the provincial departments of FAO's partner agencies (MAAH, MIWRE, MRRD) in the regions. Considering the reality in the rural areas of the country the workshops aimed to look at agriculture in the context of rural development and livelihood.

The documents of all six workshops will be printed in English, Dari and Pashto and distributed to all participants of the workshops. A sufficient number will go to the provincial departments, to the Ministries on central level and any other interested party.

At this point in time the workshop documents, together with a number of strategic papers developed by different persons and groups (including FAO's "Strategy on early rehabilitation of the agricultural sector in Afghanistan", 2002) present one of the most comprehensive collection of data and information inputs for strategic and operational development.

The workshop methodology applied is based on a strictly participatory approach combining training elements with elements of practical planning. Therefore this document contains a fruitful mixture of method and results. Most of the results discussed and agreed upon in the workshops (see chapter 12 "Strategy Planning") can be used further to develop an overall strategy for agriculture and rural development in Afghanistan, or for other sectoral planning exercises.

The process developed and the results achieved can also be utilized in a new phase or follow up of the TAPA system.

The planning issues discussed by the participants - and forwarded in this document to interested parties in Afghanistan and the international communities - do form a solid basis for conceptualization and design of projects and preparation of project proposals.

Comments, suggestions, reflections are very much appreciated.

Kabul, October 2003-10-14

Manfred Staab

FAO Programme Manager

manfred.staab@affao.org
Abdul Rahim

FAO Senior National Programme Officer abdul.rahim@af.fao.org 


\section{Table of Contents}

1. List of Abbreviations 3

2. Acknowledgement 4

3. Background 5

4. Introduction 6

5. Workshop Inauguration $\quad 7$

6. Introduction to Workshop Methodology \& Participants 8

7. Participants' Expectations $\quad \therefore .8$

8. Planning Framework 11

9. Problem Analysis 12

10. Objective Analysis 26

11. Stake-holder Analysis 40

12. Strategy Planning 50

13. Workshop Evaluation 55

14. Workshop Closing \& Adjournment 59

Annexes

\#1 Complete list of participants

\#2 Workshop Photos 


\section{List of Abbreviations}

FAO

Food \& Agriculture Organization

IOM

International Organisation for Migration

$M+E$

Monitoring and Evaluation

iNGOs

International Non-Governmental Organizations

NGOs

Non-Governmental Organisation

PPM

Project Planning Matrix

TORs

Terms of Reference

UN

United Nations

UNDCP

United Nations International Drug Control Programme

UNHCR

United Nations High Commission for Refugees

UNICEF

United Nations Children Fund

UNOCHA

United Nations Office of Coordinator for Humanitarian Assistance to Afghanistan

UNOPS United Nations Office for Project Services

WHO World Health Organisation

ZOPP "Ziel Orientierte Projekt Plannung" (Objectives Oriented Project Planning

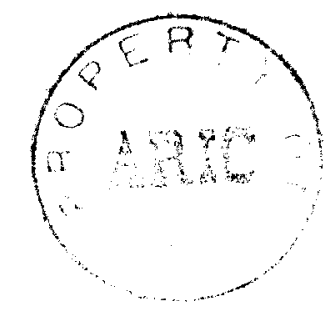




\section{Acknowledgement}

I take this opportunity to express my gratitude for the participants for their involved and valuable partaking; and, for their co-operation that made the workshop a success.

I am deeply grateful to Mr. Farid and Mr. Wahid Mohammadi for the translation and documentation support respectively, without which it would have been a nightmare to facilitate.

Of course, not to forget Mr. Rajendra Aryal and his team, who did an excellent job of keeping all the participants satisfied with the organisational matters, specially taking care of those who had come from outside of Herat.

Last but not least, I am thankful for the valuable assistance provided by the FAO Programme Office in Kabul for the workshops, in particular, the guidance and insight about the objectives by Mr. Manfred Staab, logistic and organizational support by Mr. Abdul Rahim and Mr. Omer Ibrahimi who alternatively travelled with me to the regions.

Mahmood Hemani

ViCAR Consult

vicar@cyber.net.pk

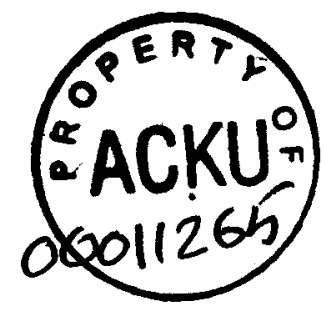




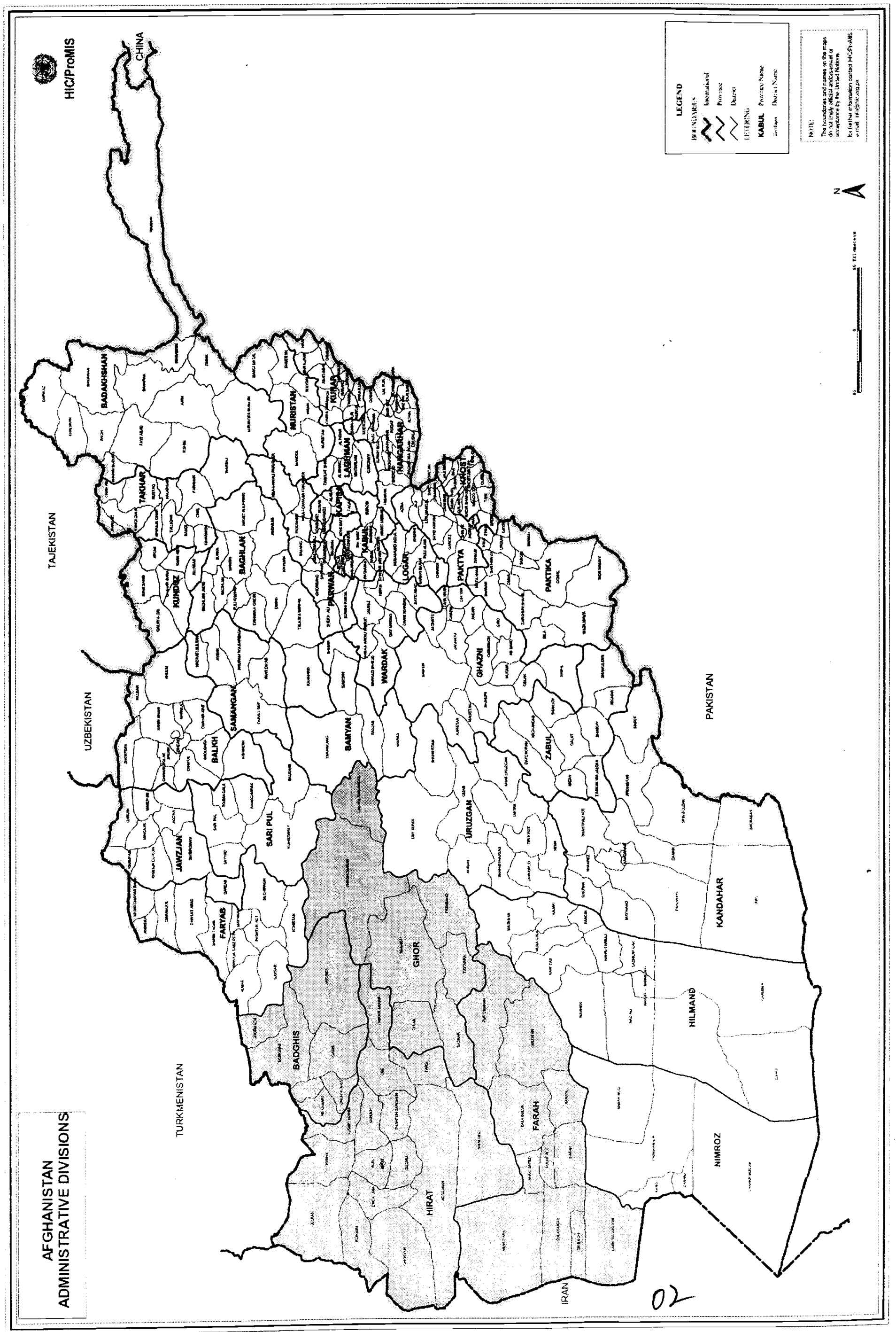




\section{Background of the western Region}

The western region of Afghanistan comprises Herat, Ghor, Badghis and Farah provinces with a population of about $2,292,600$. It has been gifted with semi-humid to arid agroclimatic conditions. The western region, together with the north and the north east, makes the largest area of rainfed 'lalmi' wheat lands in Afghanistan. Irrigated farming is also practiced in this region, mainly in the Harirud river basin. Production from the irrigated area is mainly concentrated in the lower Harirud river basin around Herat city.

Most farming is dependent upon snow melt in the mountainous areas of the region and in the lower areas on Harirud River. Wheat is the predominant autumn sown crop, which is planted between early October and mid November and harvested by the end of June. Double cropping is only possible in the lower Harirud and Murghab basins. Maize, pulses, melons, vegetables and fodder crops of annual clover and perennial Lucerne are cultivated on irrigated land as main summer crops. In the same season chickpeas are grown on poorly irrigated or rainfed land.

In the fruits and nuts category apricots, plums, peaches, apples, grapes and both sour and sweet cherries are commonly cultivated in the Harirud basin. Mulberries are widely cultivated for domestic consumption and shade trees. Illicit crops such as cannabis are also cultivated in some areas of the region for domestic consumption. In addition to agriculture farming most of the sedentary communities in the western region keep livestock such as cattle, sheep and goats, donkey, horses and silk worm for both domestic and trading purposes.

This region of the country consists of three main river basins: Harirud, Marghub and Spate of Farah. Harirud river is centered on Heart, rises in the central Hazarajat and flows westwards through the north-east of Iran before exhausting itself in Turkmenistan. The Murghub river rises in the Paropamissus range, which separates it from the Harirud basin and flows northwards into Turkmenistan. As such, the Murghab has much in common with the other rivers flowing north from the Hindu Kush. While Spate of Farah rivers are seasonal rivers with rise in the mountains of eastern Farah and Ghor provinces. They provide opportunistic irrigation as they flow westwards towards the Iranian frontier and have been seriously affected by the drought.

The region covers $16,025,812$ hectares of land. Out of this, about 537,395 hectares are irrigated agriculture, 993,430 hectares rainfed cultivated, 40,213 hectares are forest covered, 7,742,487 hectares are rangeland for livestock, 6,518,892 hectares are barren, 179,513 hectares are water bodies and 3,749 hectares are orchards covered land. Only 7,385 hectares are covered with snow in Ghor province. Except Ghor province, a total of

2,748 hectares of land is urbanised in the rest of three provinces. (FAO: Provincial Land Cover Atlas, March 1999).

The district is the smallest administrative unit of the region. The region consists of 40 districts. Out of this Herat province contains 14 districts, Ghor province 7, Badghis province 8 and Farah province 11 districts. Since 1992 many new districts have been created throughout the region, but information regarding newly created districts in the region is not available. 
Afghanistan's Projected Total Population 2003

On the basis of UNIDATA 1990 Population Estimates

\begin{tabular}{|c|c|c|c|c|c|c|}
\hline $\begin{array}{l}\text { Province } \\
\text { Name }\end{array}$ & $\begin{array}{l}\text { Dist. } \\
\text { Code }\end{array}$ & " District Name & $\begin{array}{l}\text { No. of } \\
\text { Villages }\end{array}$ & $\begin{array}{l}\text { Altitude } \\
\text { (Meter) }\end{array}$ & $\begin{array}{c}\text { Area } \\
\text { (KM2) }\end{array}$ & $\begin{array}{l}\text { Proj. Pop. } \\
2003\end{array}$ \\
\hline \multirow[t]{14}{*}{$\overline{\text { Heart }}$} & 2000 & & 1,102 & & 38,799 & $1,149,780$ \\
\hline & 2001 & Herat & 1 & 930 & 45 & 238,520 \\
\hline & 2002 & Enjeel & 225 & 920 & 1,299 & 233,693 \\
\hline & 2003 & Guzarah & 140 & 900 & 1,597 & 129,795 \\
\hline & 2004 & Pashtoon $\mathrm{Za}$. & 131 & 1100 & 1,737 & 90,422 \\
\hline & 2005 & Gulran & 118 & 920 & 5,769 & 57,402 \\
\hline & 2006 & Kushk & 133 & 1040 & 2,923 & 83,170 \\
\hline & 2007 & Ghoryan & 75 & 790 & 5,530 & 61,353 \\
\hline & 2008 & Obey & 68 & 1275 & 2,240 & 59,478 \\
\hline & 2009 & Chesht-i-Sharif & 24 & 1550 & 1,936 & 16,631 \\
\hline & 2010 & Karukh & 65 & 1360 & 2,050 & 54,630 \\
\hline & 2011 & Zendajan & 41 & 840 & 1,828 & 47,396 \\
\hline & 2012 & Kohsan & 23 & 740 & 1,406 & 38,377 \\
\hline & 2013 & Adraskan & 58 & 1340 & 10,440 & 38,913 \\
\hline \multirow[t]{8}{*}{ Ghor } & 2700 & & 867 & & 38,758 & 574,537 \\
\hline & 2701 & Chaghcharan & 133 & 2250 & 11,764 & 151,799 \\
\hline & 2702 & Shahrak & 82 & 2350 & 8,506 & 70,854 \\
\hline & 2703 & Saghar & 31 & 2100 & 2,771 & 31,994 \\
\hline & 2704 & Tolak & 60 & 2250 & 2,956 & 48,206 \\
\hline & 2705 & Taywarah & 47 & 2150 & 2,921 & 82,419 \\
\hline & 2706 & Lal-o-Sar Jan. & 452 & 2800 & 5,115 & 111,418 \\
\hline & 2707 & Pasaband & 62 & 2500 & 4,724 & 77,846 \\
\hline \multirow[t]{7}{*}{ Badghis } & 1900 & & 336 & & 21,678 & 397,096 \\
\hline & 1901 & Qala-i-Nau & 100 & 900 & 3,770 & 113,429 \\
\hline & 1902 & Kushk-i-Kohna & 42 & 1080 & 1,748 & 40,943 \\
\hline & 1903 & Morghab & 49 & 480 & 4,177 & 59,499 \\
\hline & 1904 & Ghormach & 28 & 680 & 2,160 & 46,114 \\
\hline & 1905 & Qades & 50 & 1280 & 3,354 & 74,324 \\
\hline & 1906 & Jawand & 67 & 1000 & 6,468 & 62,788 \\
\hline
\end{tabular}


Afghanistan's Projected Total Population 2003

On the basis of UNIDATA 1990 Population Estimates

\begin{tabular}{|l|c|l|c|c|c|c|}
\hline $\begin{array}{l}\text { Province } \\
\text { Name }\end{array}$ & $\begin{array}{c}\text { Dist. } \\
\text { Code }\end{array}$ & District Name & $\begin{array}{c}\text { No. of } \\
\text { Villages }\end{array}$ & $\begin{array}{c}\text { Altitude } \\
\text { (Meter) }\end{array}$ & $\begin{array}{c}\text { Area } \\
\text { (KM2) }\end{array}$ & $\begin{array}{c}\text { Proj. Pop. } \\
\mathbf{2 0 0 3}\end{array}$ \\
\hline Farah & $\mathbf{2 1 0 0}$ & & $\mathbf{5 5 2}$ & & $\mathbf{5 9 , 1 4 7}$ & $\mathbf{5 5 6 , 3 5 3}$ \\
\cline { 2 - 7 } & 2101 & Farah City & 65 & 660 & 3,535 & 124,106 \\
\cline { 2 - 7 } & 2102 & Khak-i-Safaid & 10 & 680 & 1,359 & 19,787 \\
\hline 2103 & Shindand & 127 & 1066 & 8,498 & 130,511 \\
\cline { 2 - 7 } & 2104 & Farsi & 48 & 2270 & 2,500 & 27,040 \\
\hline 2105 & Anar Dara & 31 & 770 & 10,610 & 26,060 \\
\cline { 2 - 7 } & 2106 & Bakwa & 42 & 720 & 2,081 & 23,532 \\
\cline { 2 - 7 } & 2107 & Bala Blook & 31 & 565 & 6,256 & 44,842 \\
\cline { 2 - 7 } & 2108 & Qala-i-Kah & 63 & 1400 & 6,602 & 27,369 \\
\hline 2109 & Gulestan & 55 & 1900 & 7,154 & 45,354 \\
\hline & 2110 & Purchaman & 30 & 500 & 5,229 & 31,279 \\
\hline
\end{tabular}




\section{INTRODUCTION}

This report covers the proceedings and results of a five-day workshop held in Herat from $17^{\text {th }}$ to $21^{\text {st }}$ June, 2003 to prepare an overall strategy for the Agriculture sector and (allied) Rural Development in the western region of Afghanistan. The provinces covered under the strategy are Herat, Farah, Ghor and Badghiz.

The planning methodology used in the workshop is based on ZOPP. ZOPP is the acronym for the German term "Ziel Orientierte Projekt Plannung" (Objectives Oriented Project Planning). ZOPP is a participatory planning methodology that uses a sequence of successive steps leading to a planning matrix which illustrates the basic structure of the overall programme/project. However, due to the very nature of the event, the workshop did not attempt to workout indicators and assumptions.

The workshop was attended by the representatives of provincial departments and sections from Agriculture (incl. Livestock), Irrigation, Rural Development, and Planning; representatives of local and international NGOs, UNAMA and regional staff of FAO office and projects. The Coordinator of UNAMA inaugurated the workshop and the Deputy Governor joined for final presentation and closing. A complete list of workshop participants is presented in annex \#1.

The workshop was conducted in a fashion that simultaneous English to Pashto/Dari and vice versa translations were done to ensure full participation of all. This process, though it took time, greatly helped the participants to discuss and express their opinion in their native language thereby avoiding any misunderstanding due to language constraints. To facilitate the translation business, workshop utilised the expertise of two translators who not only did translations but also greatly helped in getting the messages across.

The workshop succeeded in achieving the objectives assigned to it. On pure technical grounds, the analyses and strategy $m$ ay s till be deficient and c an certainly be improved; however, the uniqueness of the products is that these are the heart-felt priorities of the people of the region. Thus, the distinctive value of workshop outcomes deserves its due importance to be realized, as expressed right at the beginning of the workshop (see participants' expectations).

Additionally, for the participants, the workshop provided a rare opportunity to such a diverse, yet closely allied professional group to collectively contemplate the existing situation and the future direction. Also, a unique exposure to planning technique, teamwork, broad thinking and taskoriented participation has resulted in full ownership of the "strategy".

The Afghans are known for their hard works, however, the turbulences of a quarter of century have made this country extremely resource starved. Thus, it cannot on its own re-build itself and it is now the responsibility of the aid community to help realize the strategy.

It would be beneficial for the interim Afghan Government to integrate the strategy - prepared by Afghans themselves, into the overall development agenda and start initiation of the "resourceneutral" tasks. This, on one hand would enhance the confidence of the people in the strategy, while, on the other, it would signal the donors that the prerequisites are being done and may facilitate in early partnership agreement(s). 
The workshop started with the recitation of few verses from the Holy Quran.

Mr. Rajendra Aryal, FAO Area Manager in Heart welcomed the participants and said that this is a developmental workshop and a major leap in the advancement of the projects in near future. He requested the participants to openly share their ideas and collectively find a way forward for the development of war torn Afghanistan.

He stated that such workshop would give the participant a unique exposure to planning technique that can also be used in daily life, thus, he appealed for continuous participation. He further stated that the workshop is of practical nature and would greatly contribute in enhancing the capacities.

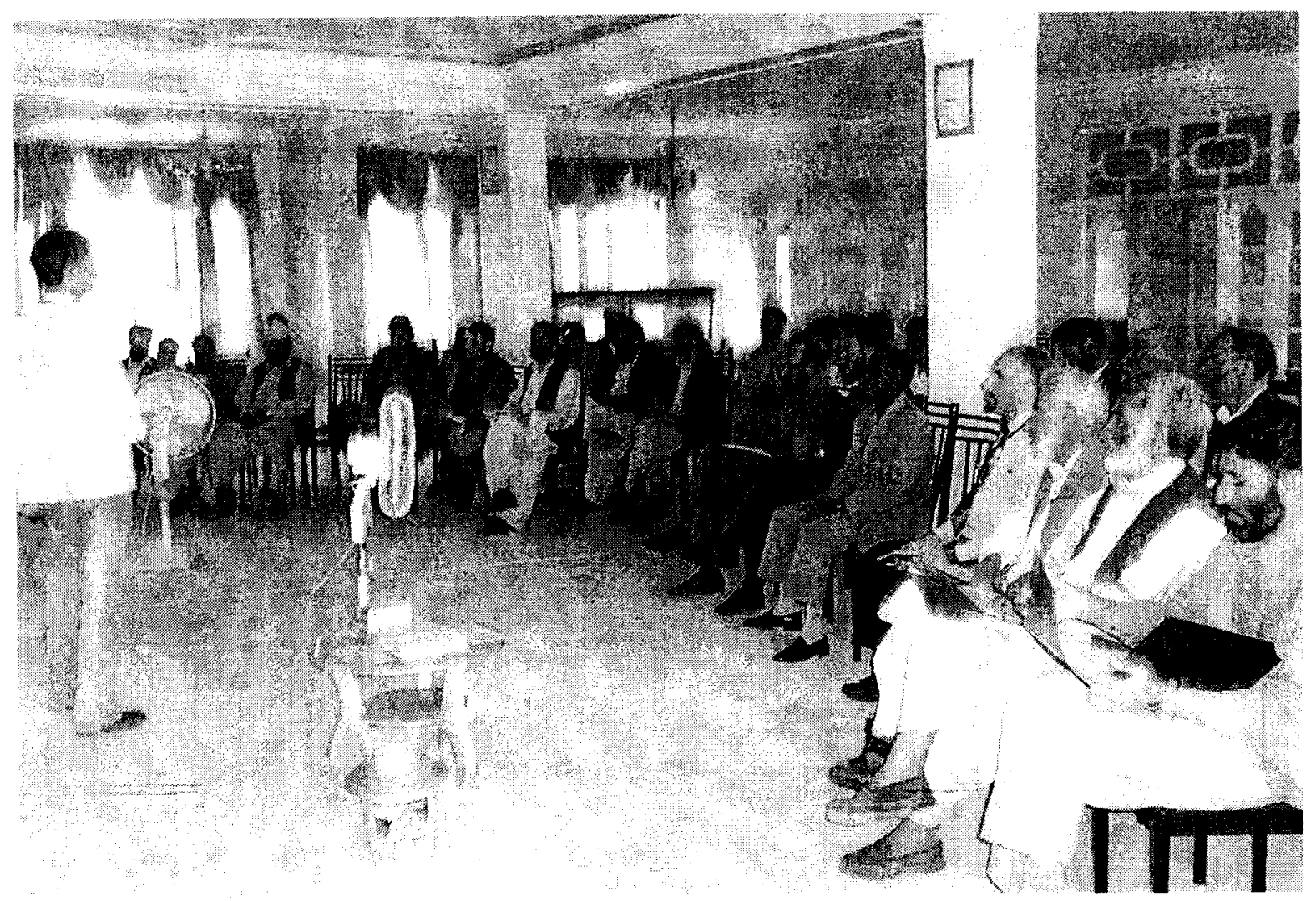

Mr. Abu Diek, Coordinator of UNAMA in Herat extended warm welcome to the participants and thanked the FAO for organizing it. Agriculture holds the key to rural development, thus, he requested the participant to take the maximum benefit of the event and to discuss the related problems of the region and the solutions for each. He wished the workshop all the success in coming up with a strategy for the development of the agriculture in the western region. 


\section{Introduction to Workshop Methodology \& Participants}

After the inaugural session, workshop timings were worked out to accommodate prayer timings together with the lunch and tea breaks. Later, the chart and card technique was explained to the participants.

A brief overview of the steps of the ZOPP method and the design of the PPM were explained. In addition to this brief introduction, before the start of each step detailed understanding into how to do the exercises were also given.

Later, the participants introduced themselves verbally by giving their names, designation and organisation. A complete list of workshop participants is presented in annex \#1.

\section{Participants' Expectations}

The group was then invited to state their main expectations of the workshop on the cards; these were then shared with the plenary. Participants wrote expectations pertaining to the overall workshop as well as some too specific issues. Understanding was developed that the very specific statements (desires) pertaining to the contents of the plan will be cross-checked at later stages of the workshop.

Majority of the cards highlighted the need for preparation of strategy for agriculture and rural development.

Some participants also suggested the norms for the workshop, while a few stated their desire to learn planning techniques, proposal writing, team work as well as to learn technicalities of agriculture.

Quite a number of the participants stated their desire that "plan should be implemented". Presenting clarification on this, participants stated that such planning workshops have been done in the past several years, but, very few of the plans have been implemented. There are deep rooted apprehensions and these can only be removed with the adequate support of the international community.

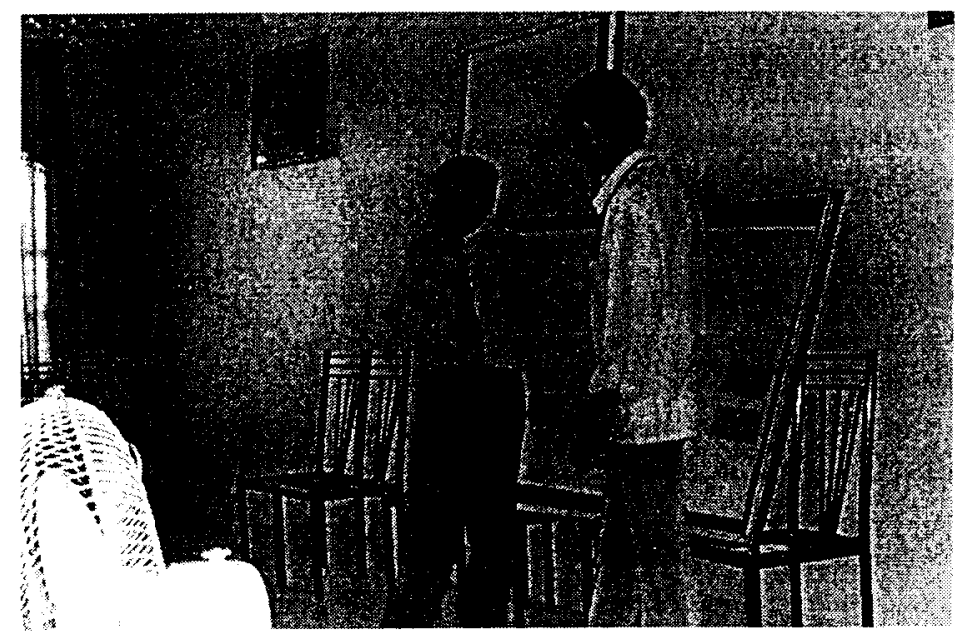




\section{United Nations - Food \& Agricultural Organization, Afghanistan \\ PARTICIPANTS' EXPECTATIONS \\ FOR AGRICULTURAL \& RURAL DEVELOPMENT \\ IN WESTERN AFGHANISTAN \\ (Herat, Farah, Ghor \& Badghiz Provinces)}

\section{Workshop expectations}

- Making an agriculture strategy for Afghanistan.

- Finding of appropriate strategy and plan for rehabilitation of agriculture sectors

- Finding the best way of agriculture developments and removing constrain and problems

- To find the best way of unified strategy making for all rural agriculture developments.

- To develop effective strategy for rural developments of southwest zone of Afghanistan.

- Strategy for rural developments

- Specific strategy for rural agriculture development and planning project

- Strategy for rural developments in western region

- The work shop would be applicable

- Discussion about the plan and activity of projects in future

- Constructive planning \& monitoring

- To enable us to analyze community problems

- Issues discussed in the workshop should be applicable

- Planning should implement to right way can effective

- If is possible the workshop should be reduce the time from 8:00 am up to 4:00 pm and more days.

- If is possible the (number of days of) workshop should be enlarged (increased)

- Increase the days of workshop and decrease the time of it

\section{Personal expectations}

- To improve the knowledge of agriculture by this workshop

- Upgrade planning abilities

- To learn preparation of projects planning.

- To learn better how prepare and plan the projects

- How to work as team

- Workshop should explain more.

- To learn the issues, design of planning and the action

- To leam implement about our plan

\section{Specific expectations}

- Managements of water between farmers.

- In this workshop we would like to know about managements and distribution of agriculture water.

- Finding a better irrigation system

- About forestry rehabilitation decision should be made.

- Improve education and economic of agriculture.

- Such workshop should help the farmers and improve their living condition

- To learn the workshop we able to improvements in project 


\section{Planning Framework}

The decades of turbulences has affected every aspect of existence and has resulted in the psyche that all problems related to every walk of life are raised whenever an opportunity is made available. In order to help maintain the focus on the subject matter of the workshop, participants were facilitated to agree upon the planning framework.

The framework underscored the geographical and sectoral precincts for all subsequent works carried out in the workshop culminating with the strategy. The session aided in gaining clearer understanding by the group on the factors that will be addressed by the workshop for the planning purposes. At the same time, it also highlights the key concerns the people had in mind for the analysis of situation.

\begin{tabular}{|c|c|c|}
\hline \multicolumn{3}{|c|}{$\begin{array}{l}\text { United Nations - Food \& Agricultural Organization, Afghanisțan } \\
\text { PLANNING FRAMEWORK } \\
\text { FOR AGRICULTURAL \& RURAL DEVELOPMENT IN } \\
\text { WESTERN AFGHANISTAN }\end{array}$} \\
\hline Region: & \multicolumn{2}{|l|}{ Western } \\
\hline Provinces: & \multicolumn{2}{|c|}{$\begin{array}{l}\text { - } \text { Herat } \\
\text { - Farah } \\
\text { - Ghor } \\
\text { - Badghiz }\end{array}$} \\
\hline \multicolumn{3}{|c|}{$\begin{array}{l}* \text { Agricultu } \\
* \text { Rural De }\end{array}$} \\
\hline \multicolumn{2}{|l|}{ Sub-Sectors } & Crosscutting Elements \\
\hline $\begin{array}{l}>\text { Horticultur } \\
>\text { Forestry } \\
>\text { Livestock } \\
>\text { Animal He } \\
>\text { Irrigation } \\
>\text { Cereal Cro } \\
>\text { Industrial } \\
>\text { Sericulture } \\
>\text { Watershed } \\
>\text { Range Man }\end{array}$ & $\begin{array}{l}\text { oduction } \\
\text { th } \\
\text { Aanagement } \\
\text { gement }\end{array}$ & $\begin{array}{l}\text { - } \\
\text { - } \text { Marketing: } \\
\text { - Processing } \\
\text { - Storage } \\
\text { - Packaging } \\
\text { - Inputs } \\
\text { - Environment } \\
\text { - Infrastructure (rehab \& } \\
\text { development) } \\
\text { - Capacity Building of: } \\
\text { - Farmers } \\
\text { - Service Providers }\end{array}$ \\
\hline
\end{tabular}




\section{Problem Analysis}

After the agreement on "planning framework", the workshop continued into the much awaited analysis of problems. The purpose of the problem analysis is:

Identify and analyse the major problems surrounding the given condition. Arrive at a group consensus about the core problem, which describes the central point of the overall problematic condition, and visualise the cause-effect relationships in a Problem Tree.

To begin with, each participant was given the opportunity to write one problems on a card which they considered to be an important problem. While sharing the submissions of the first round of brainstorming, the clustering of corresponding cards highlighted the six centres of attention; these were:

- Agriculture

- Irrigation

- Livestock

- Forests

- Rural Communities, and

- Government Institutions

The next step was to identify a core-problem of the situation. This proved to be an arduous task for the group - majority of whom were having their first exposure to such exercise. The different suggestions given by the participants varied from war/fighting, lack of funds, illiteracy to weak economy and unstable government. This led to the discussion about the difference in root problem, core-problem, causes and effects. The group reached consensus to focus on "systems approach" and concentrate on situation analysis from the overall "production" point of view. By the end of the day the participants agreed on the following statement as core-problem:

\section{"improper management and production system"}

Day 2

The plenary was then divided into seven subgroups, one each for effects and the six principal causes (areas) of the core-problem. The assigned task was to continue with the problem analysis in sub-groups for allocated topic in greater details and in their own languages. This not only resulted in expeditious completion but generated wider understanding of the situation. The outcomes of the group work were shared with the plenary where certain adjustments were made to the final product.

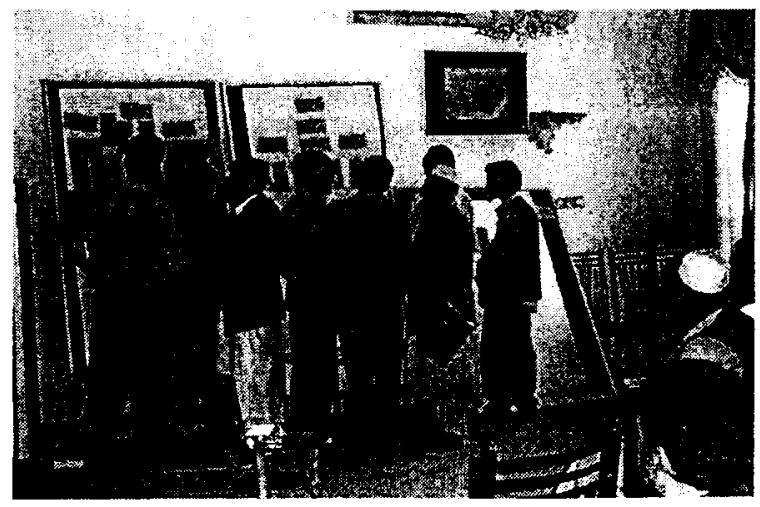

By the end of second day the workshop succeeded in completing the Problem Tree. The next page presents the core problem, all the identified effects and major problems. The causes to the major problems are presented on the subsequent pages; these are the resultant charts of the group work analysis 


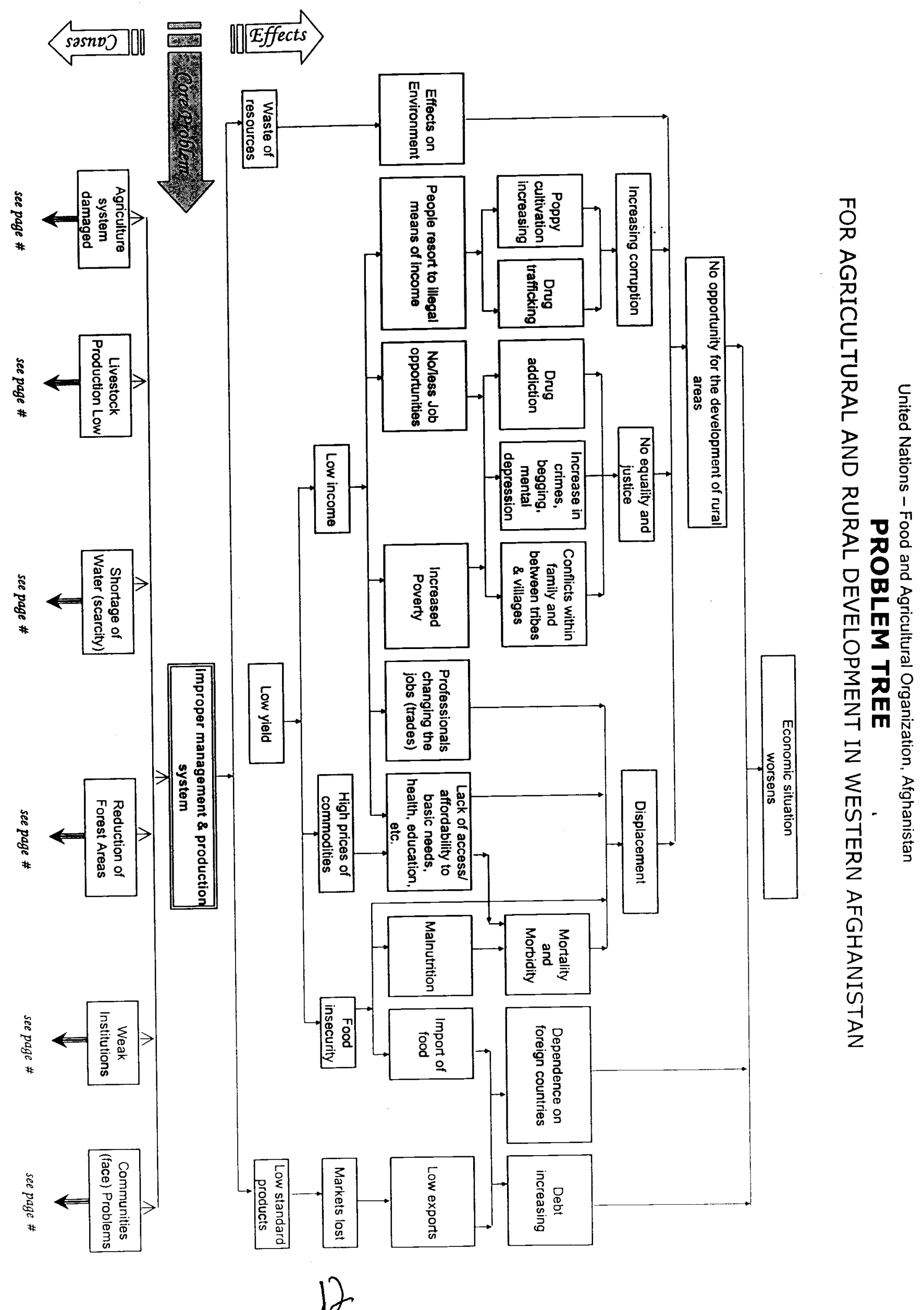




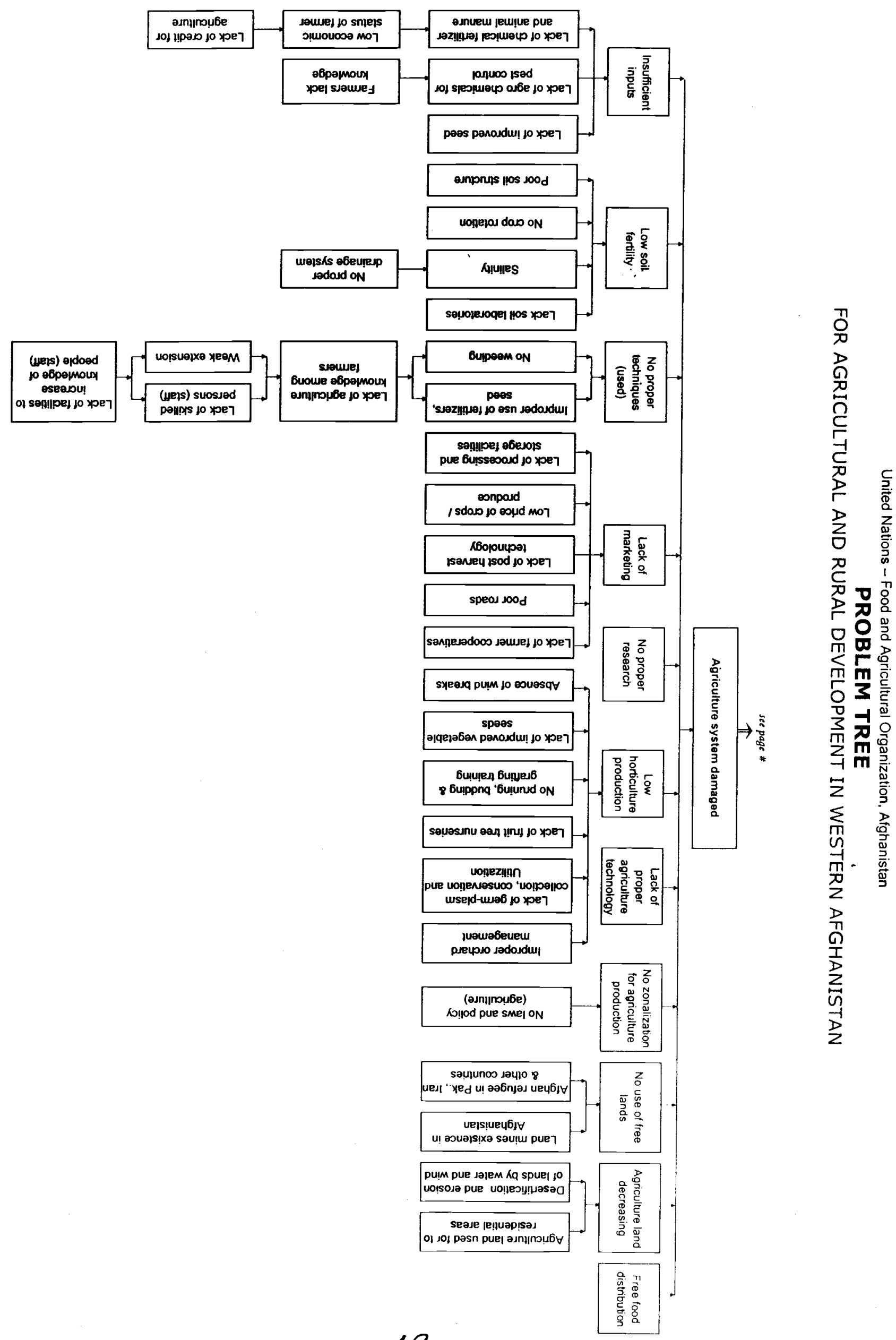




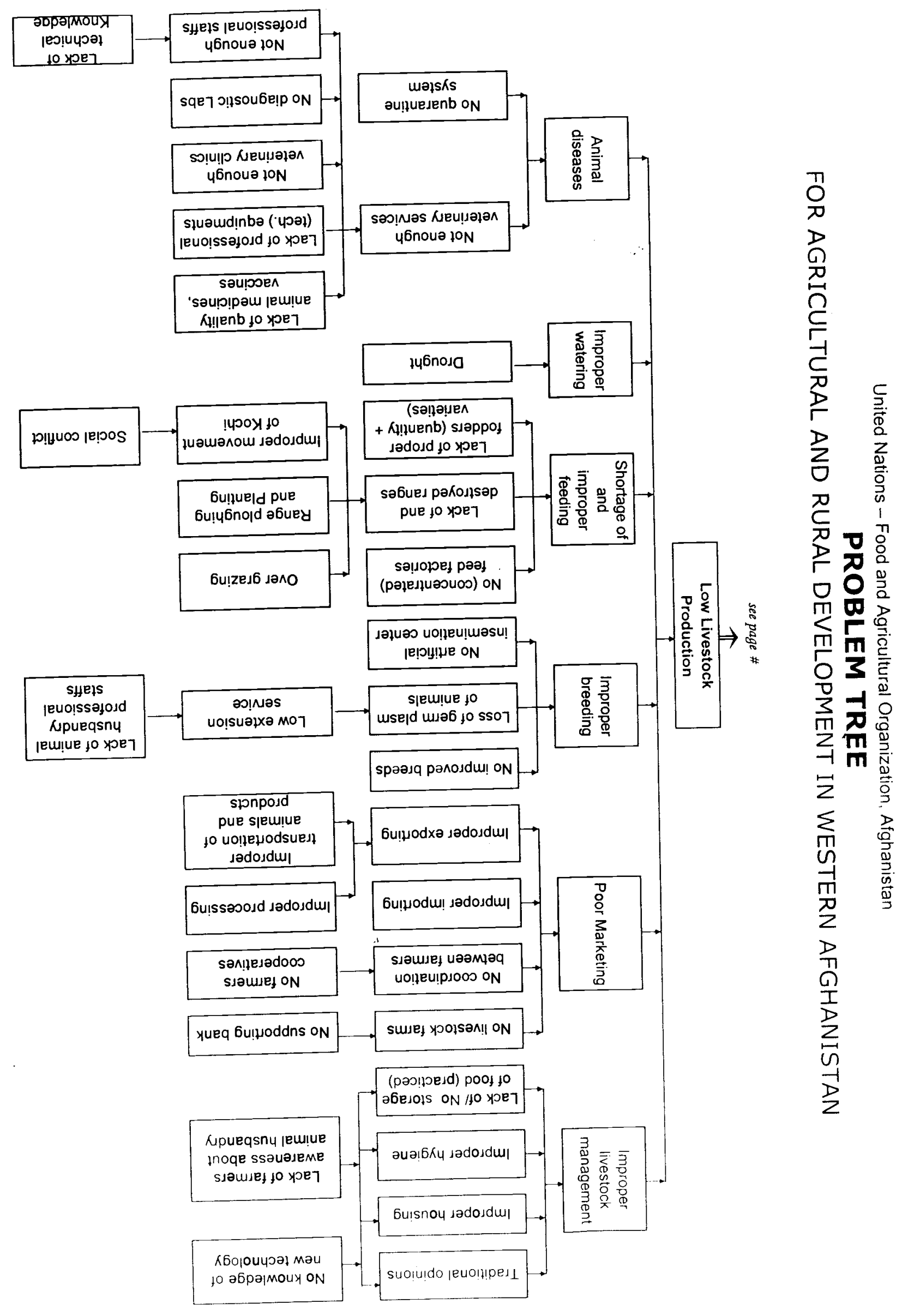




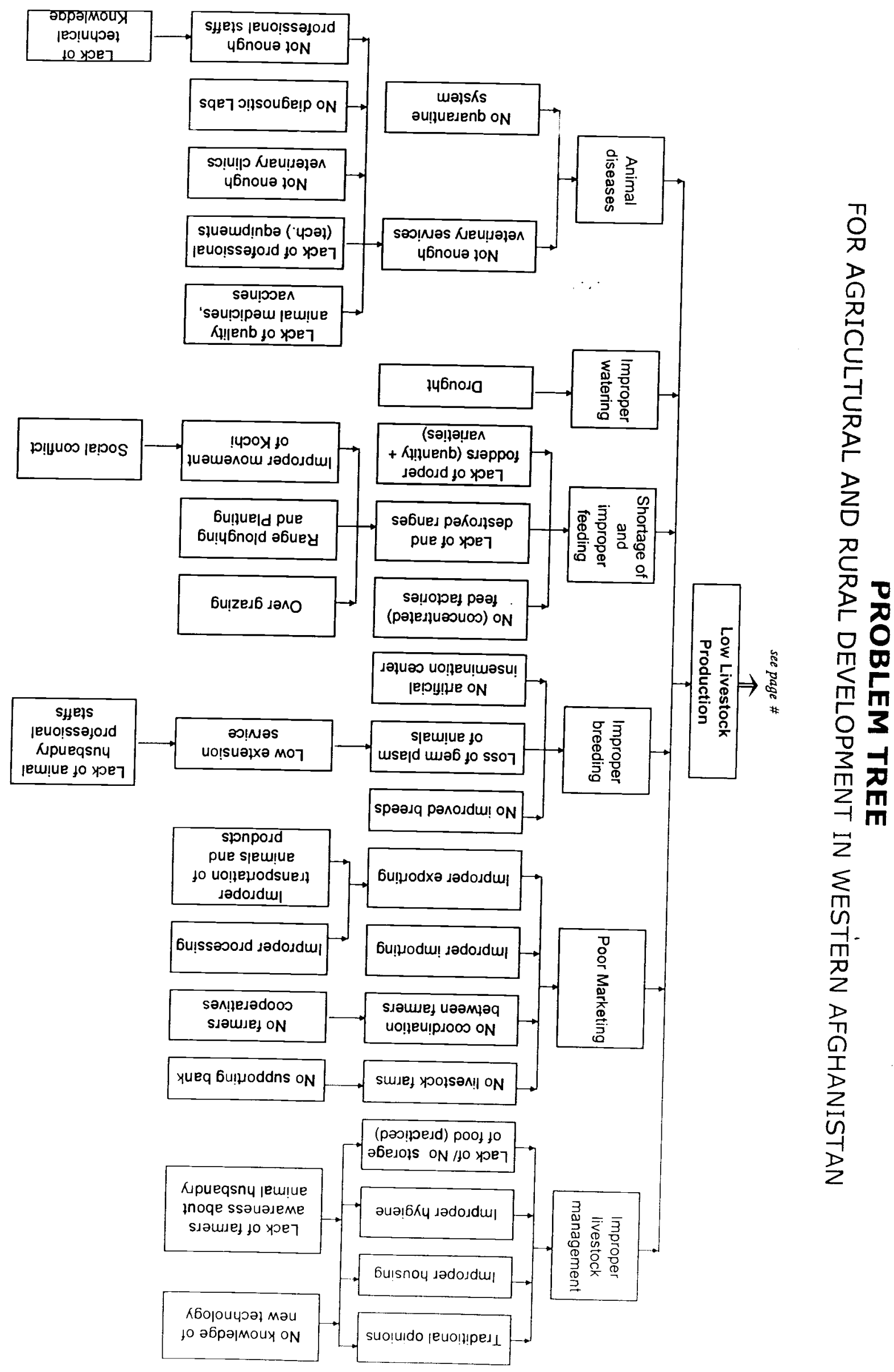




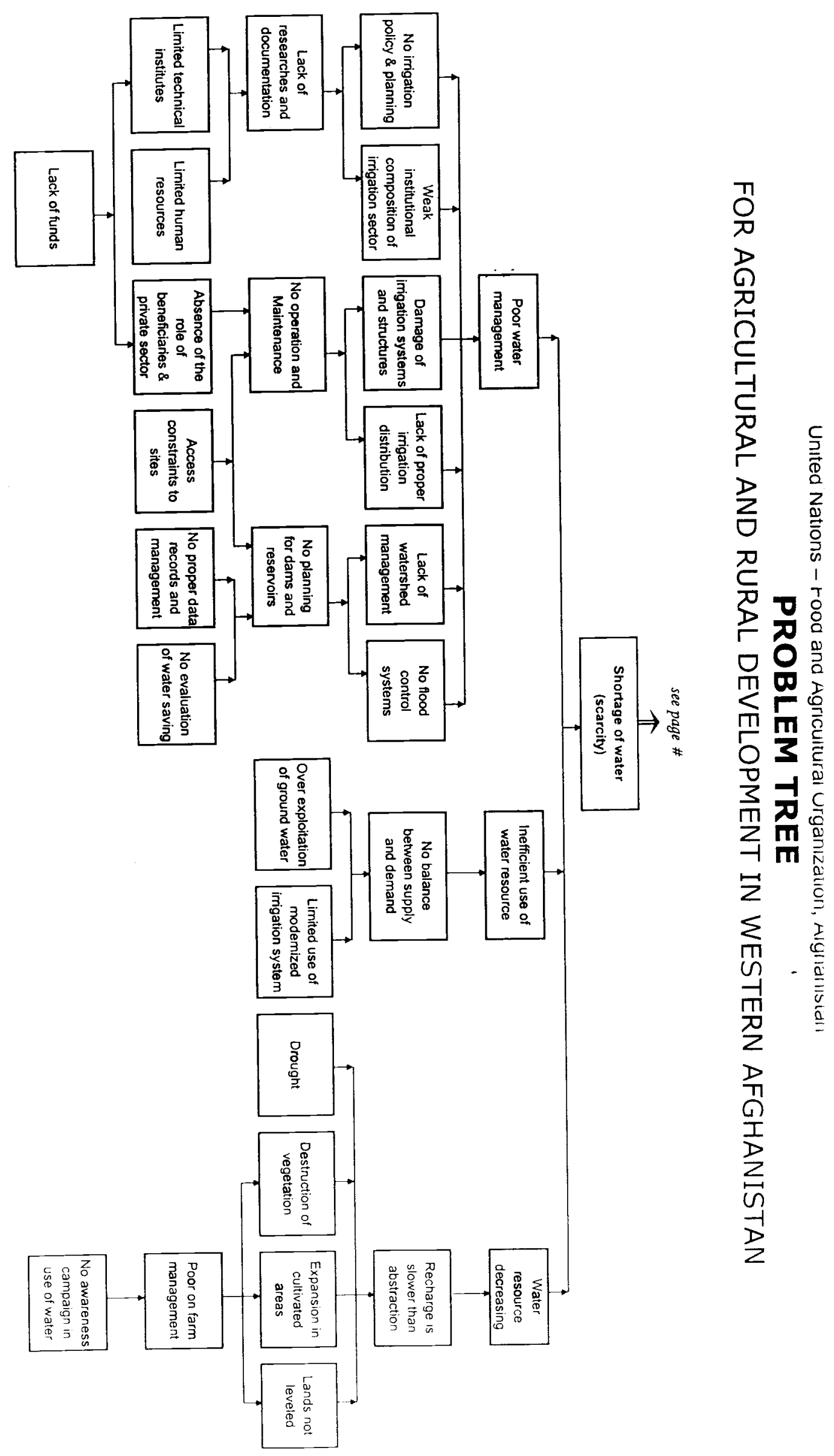



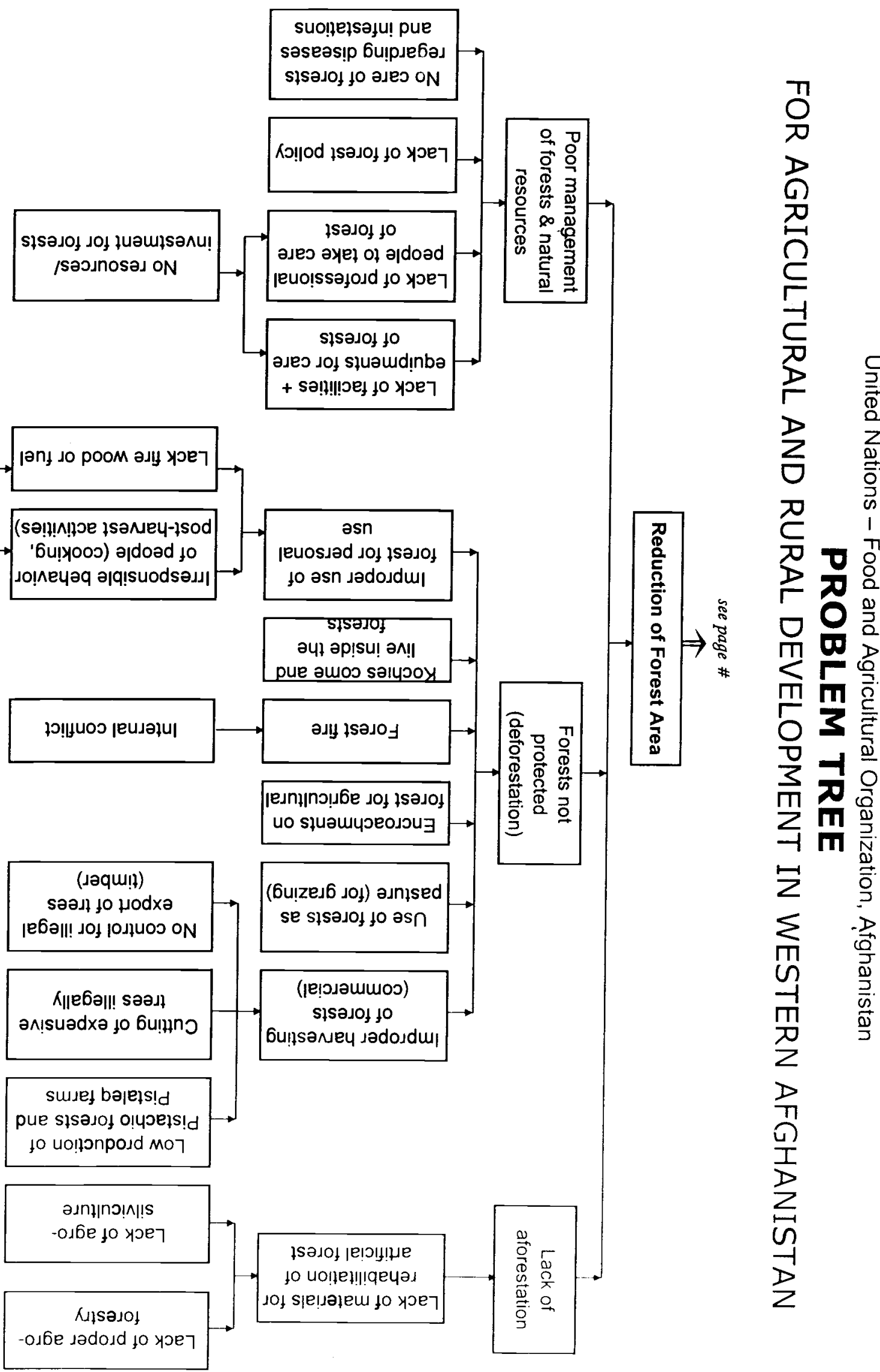


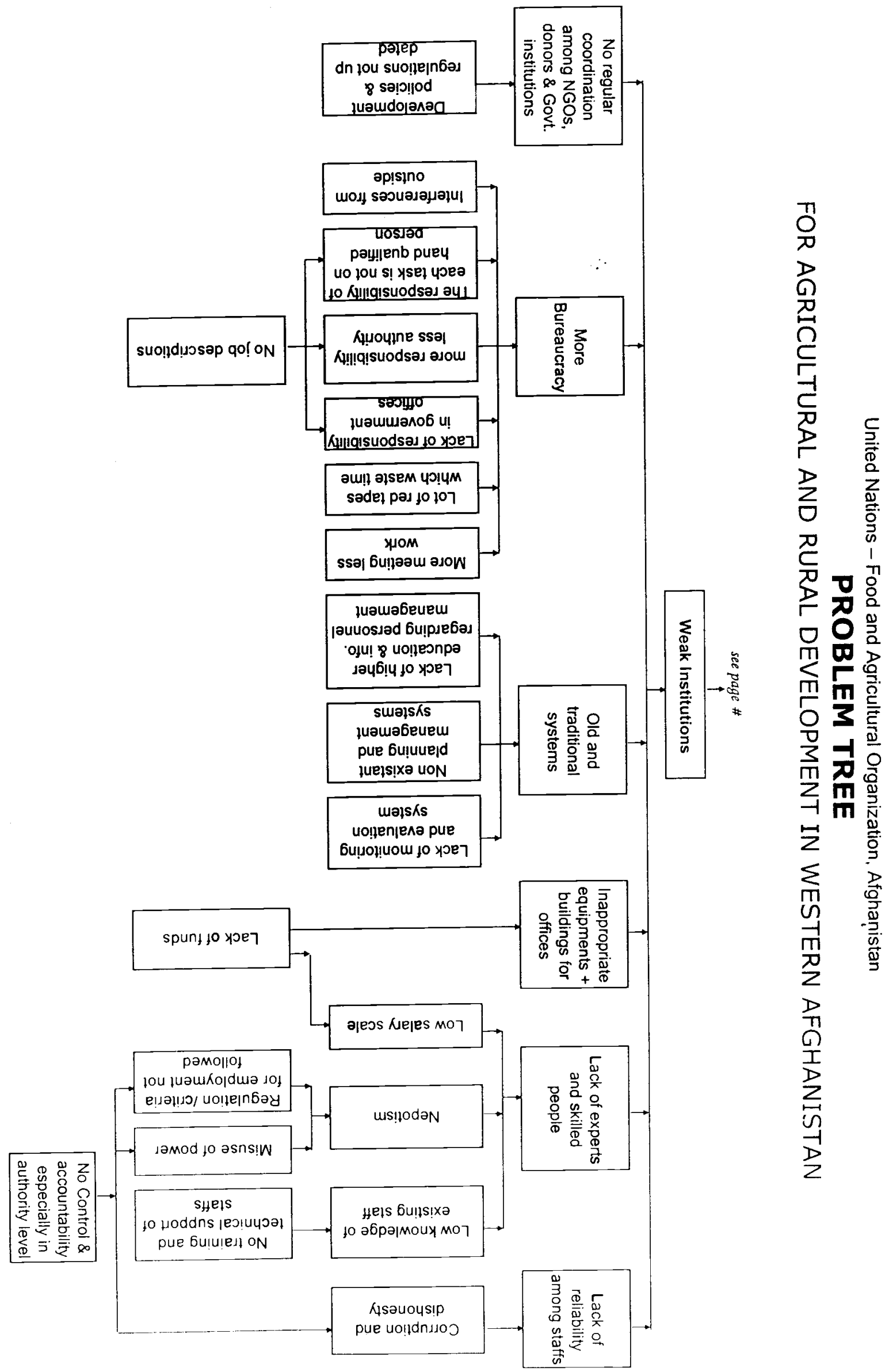




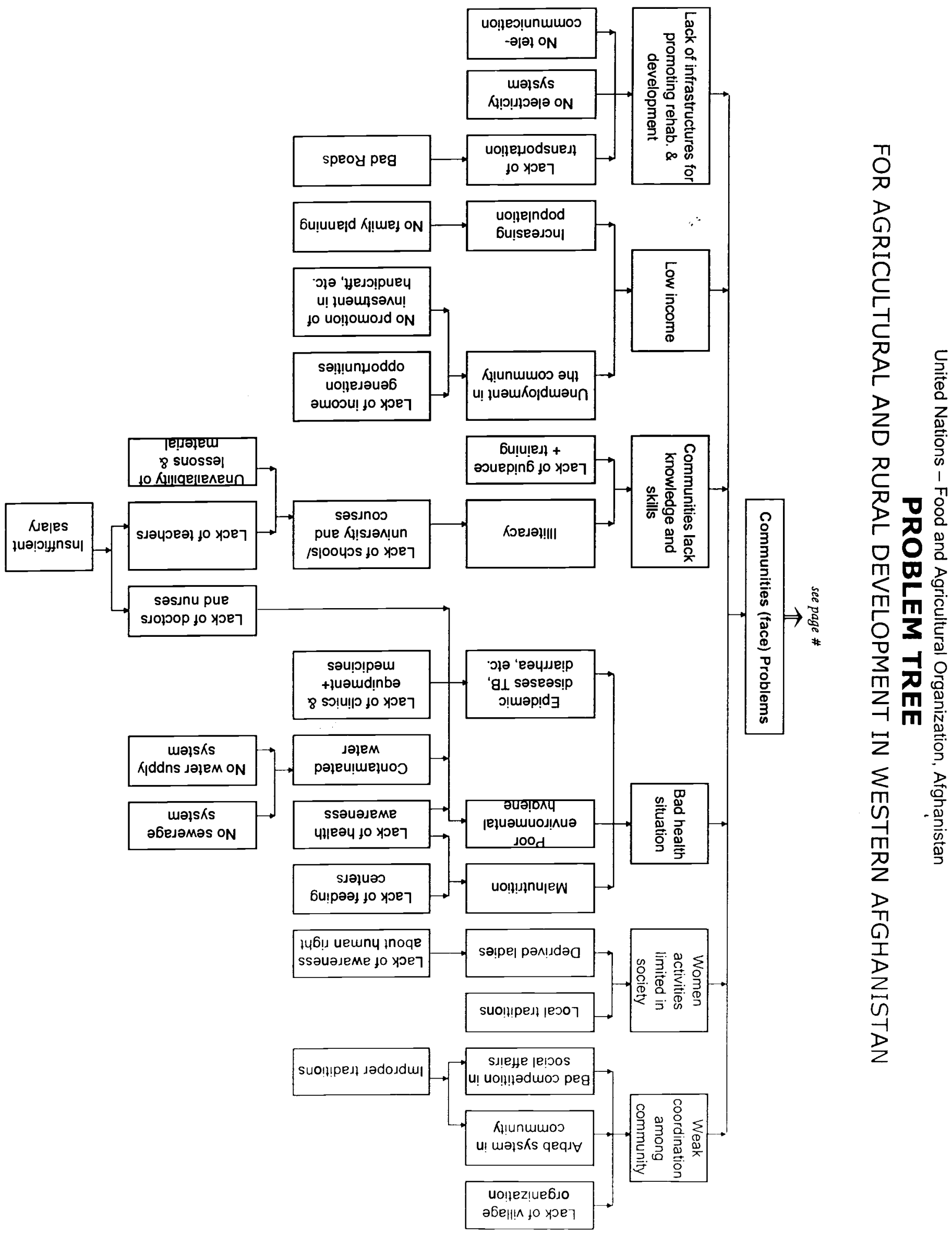




\section{Objective Analysis}

After the problem analysis, which described the depressing existing situation, an objective analysis was made. The purpose of the objective analysis is:
All the problem statements in the Problem Tree are transformed into positive, describing the future situation that will be achieved by solving the problems.

The guiding principles for formulation of objectives were to assess the statements for a) it is desirable, and $b$ ) is realistically achievable. Also, alternative solutions were to be found for the problems that were insoluble or that the objectives were inexpedient. Furthermore, additional objectives for achieving the ends (stated at next higher level) were to be added during the analysis to complete the means-ends relationship.

At first, in plenary, a handful of objectives were formulated to generate understanding of the task. Later, the sub-groups worked out the objective statement for the assigned parts of the problem tree.

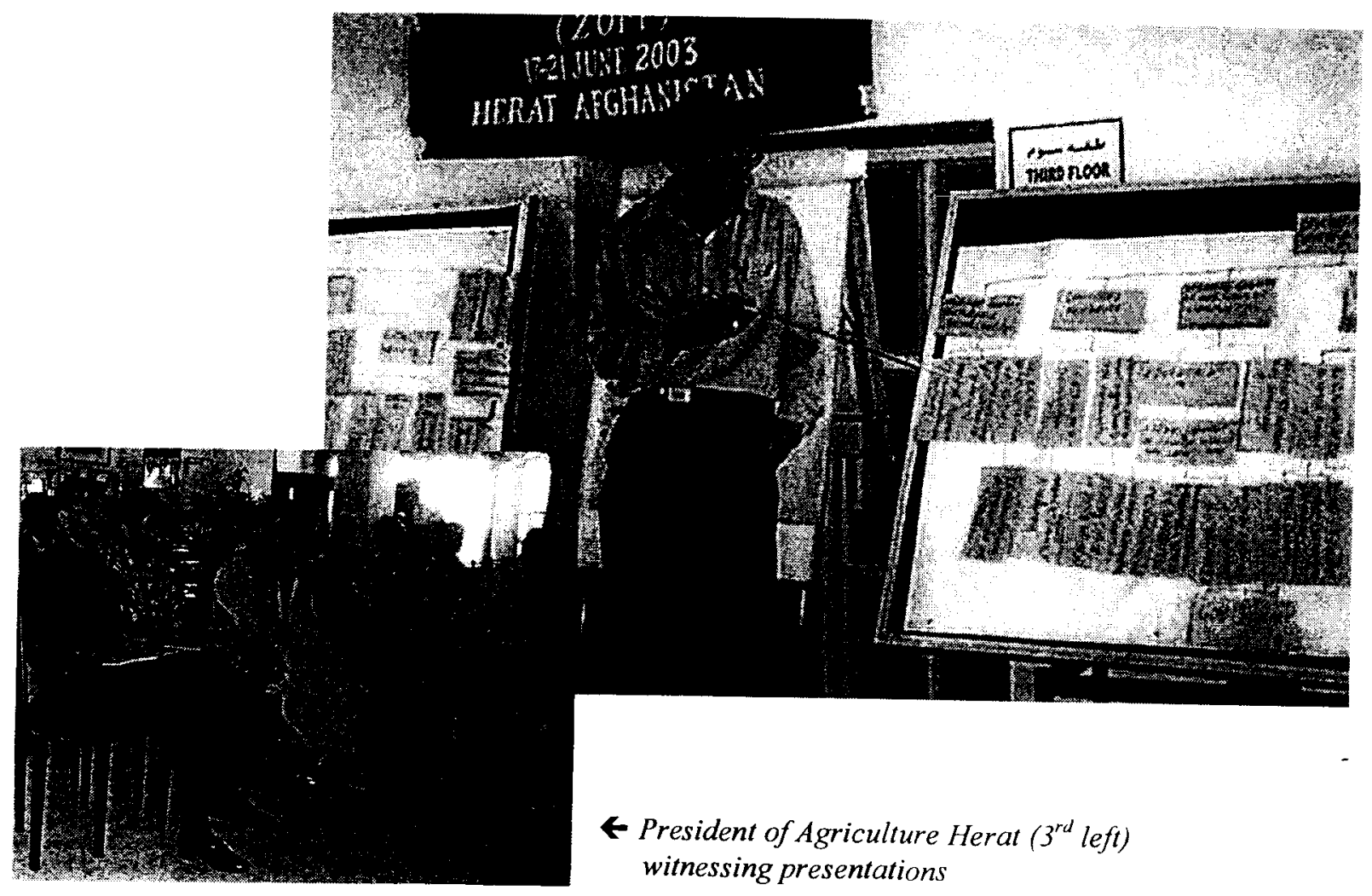

During the plenary presentations of the sub-group works, the whole of objective tree was verified for completeness and agreed upon suggestions were added to the analysis

The step was considered as a welcome change by the participants since they were no longer talking about the negative situation but instead about future state which the strategy would achieve

The Objective Tree constructed by the participants is presented on the following pages. 


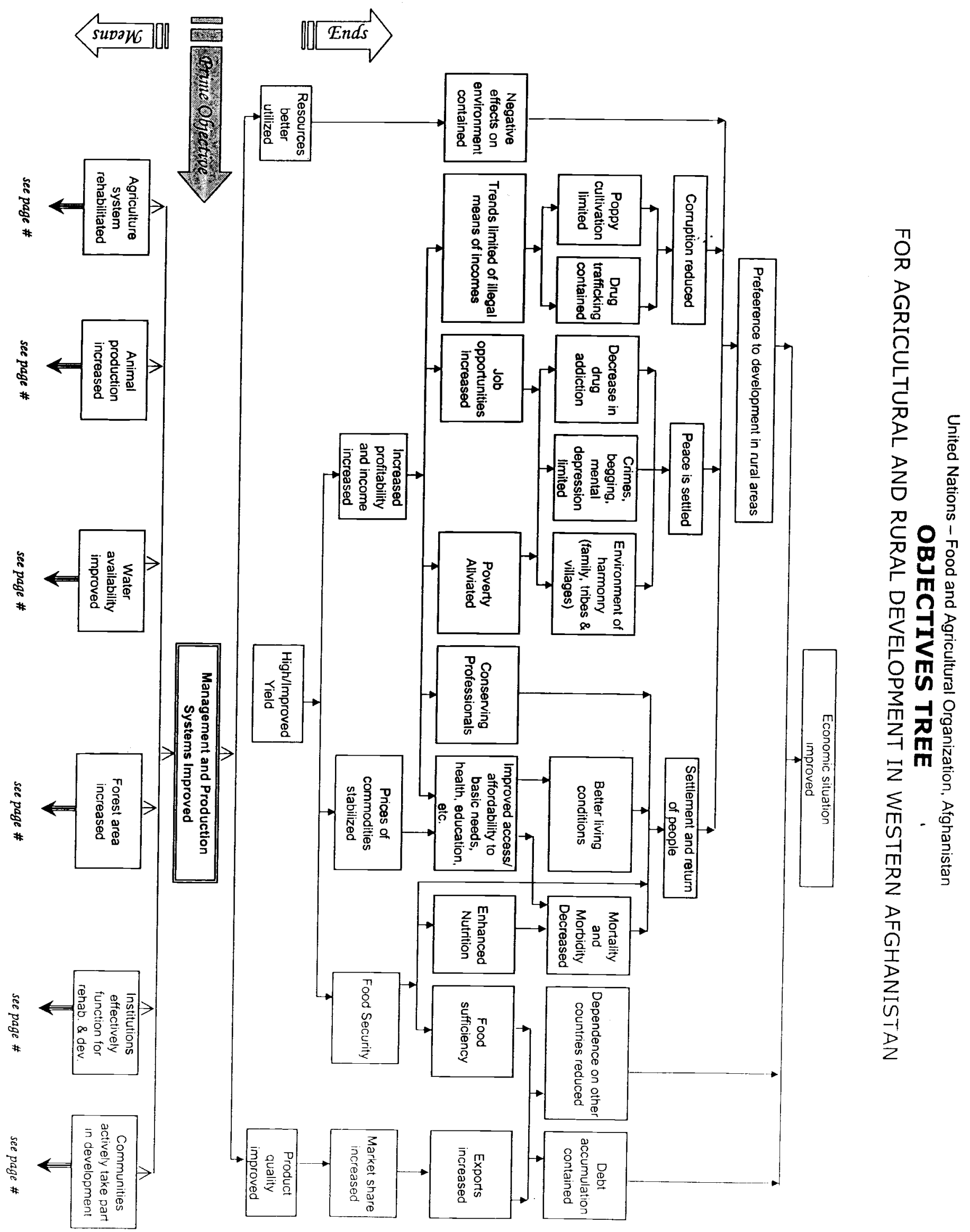




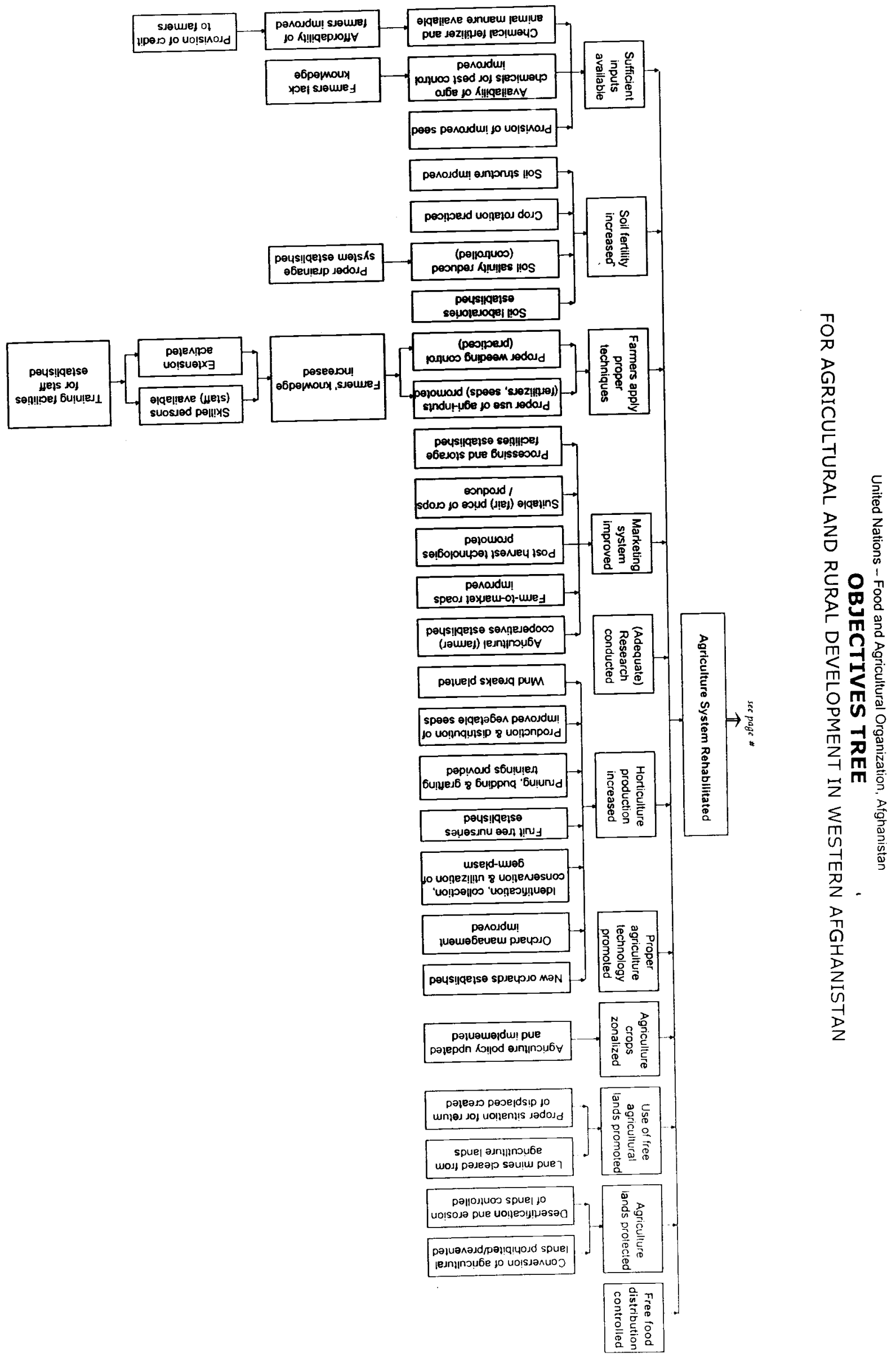




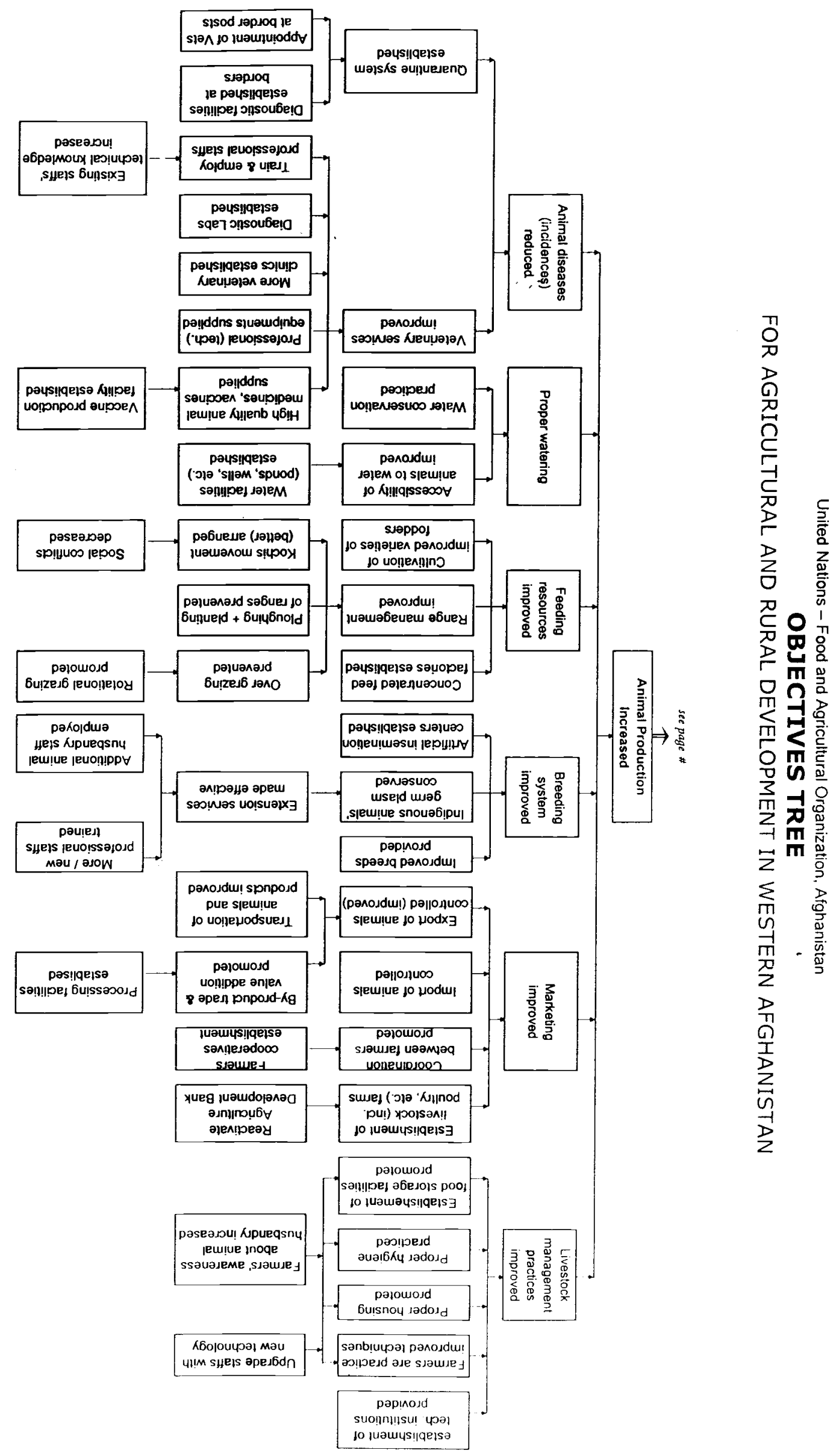




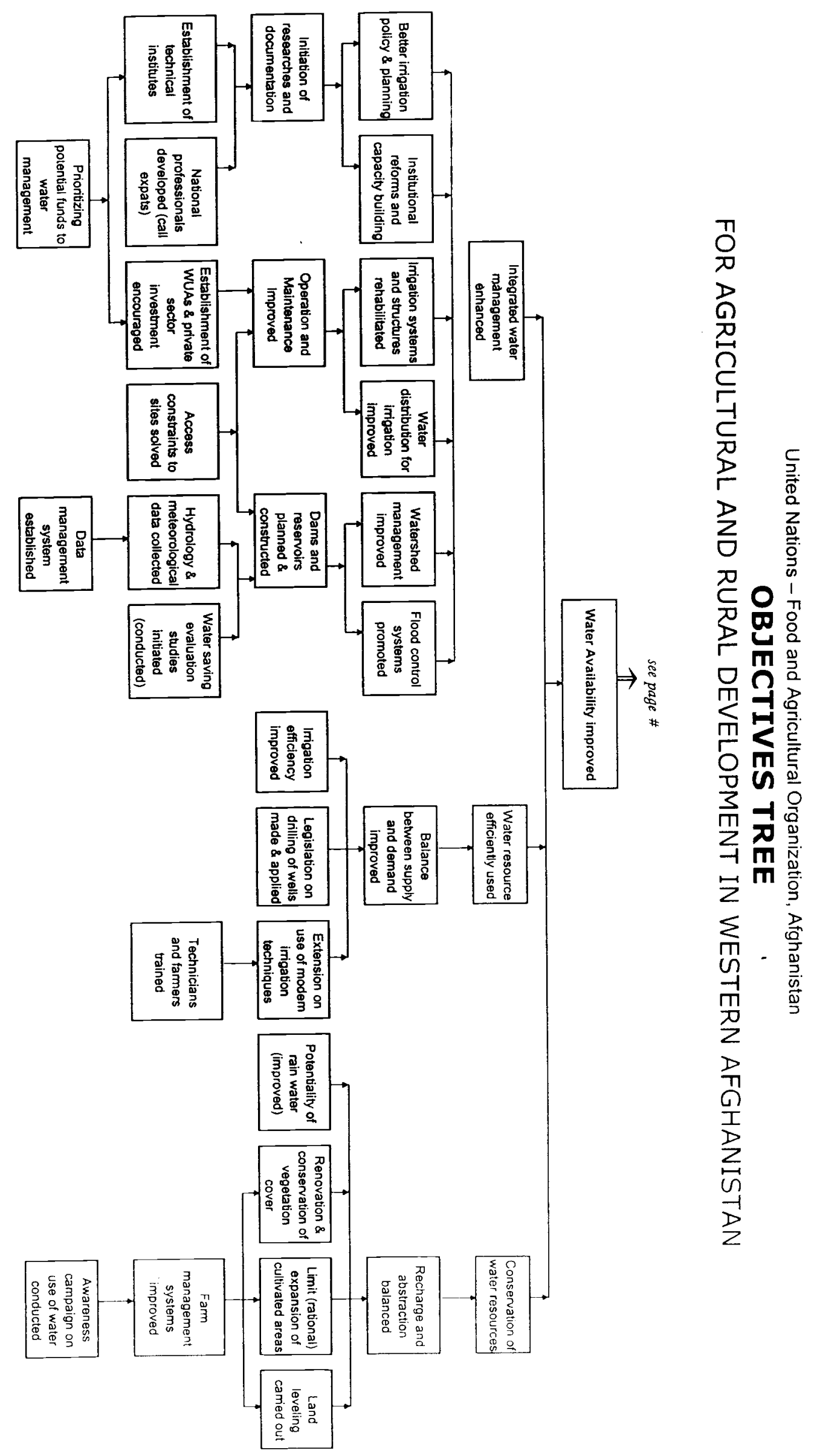



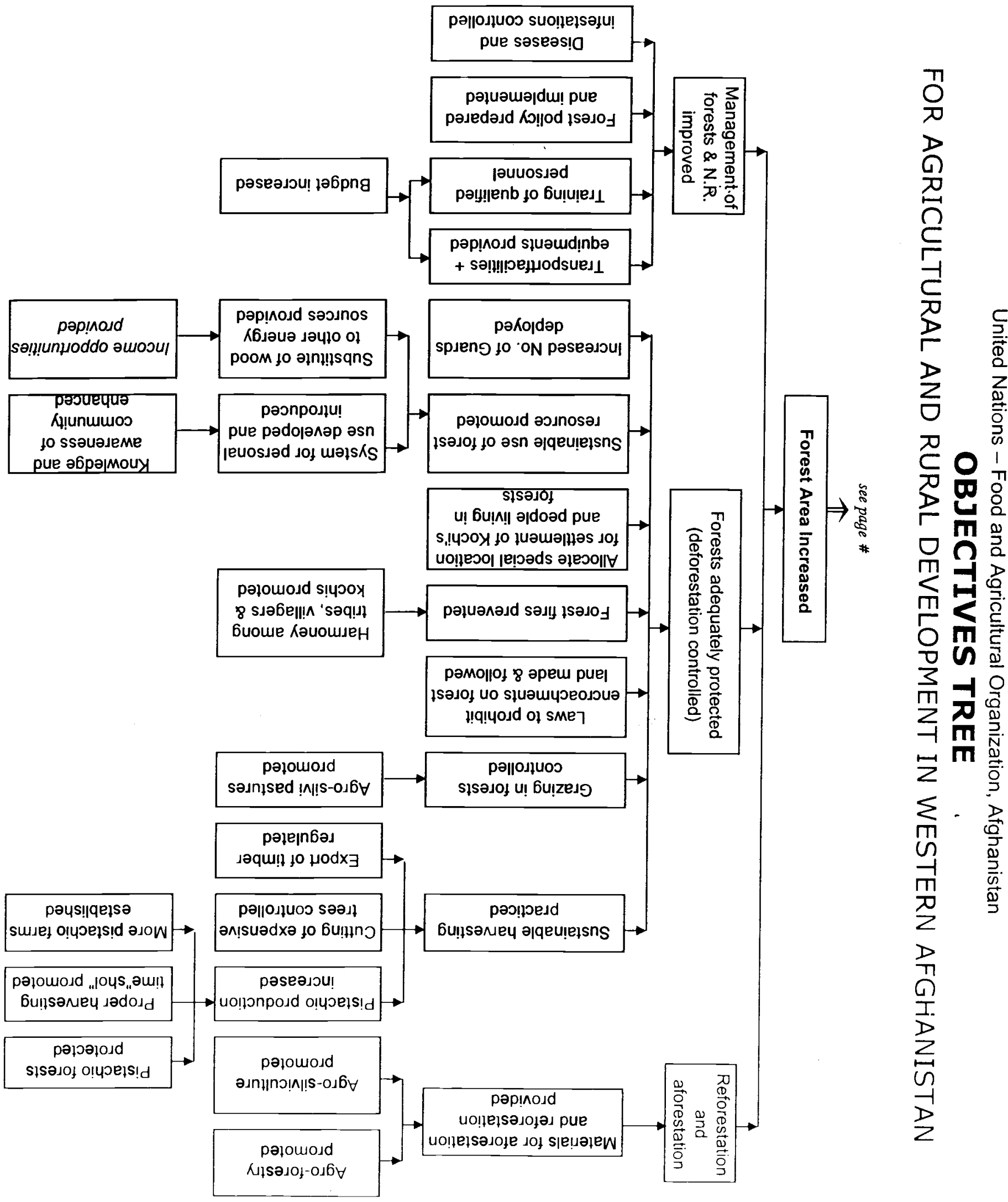


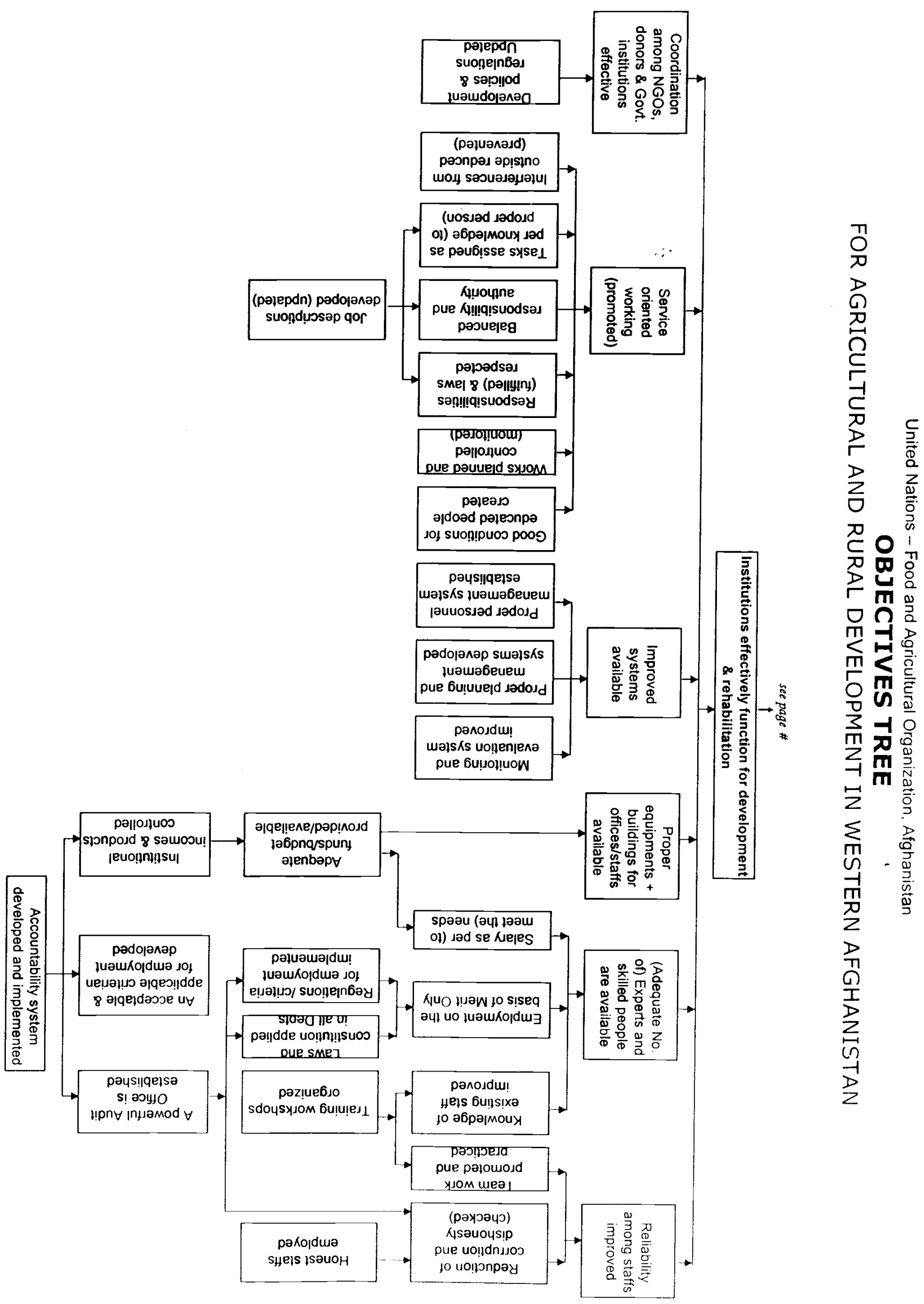




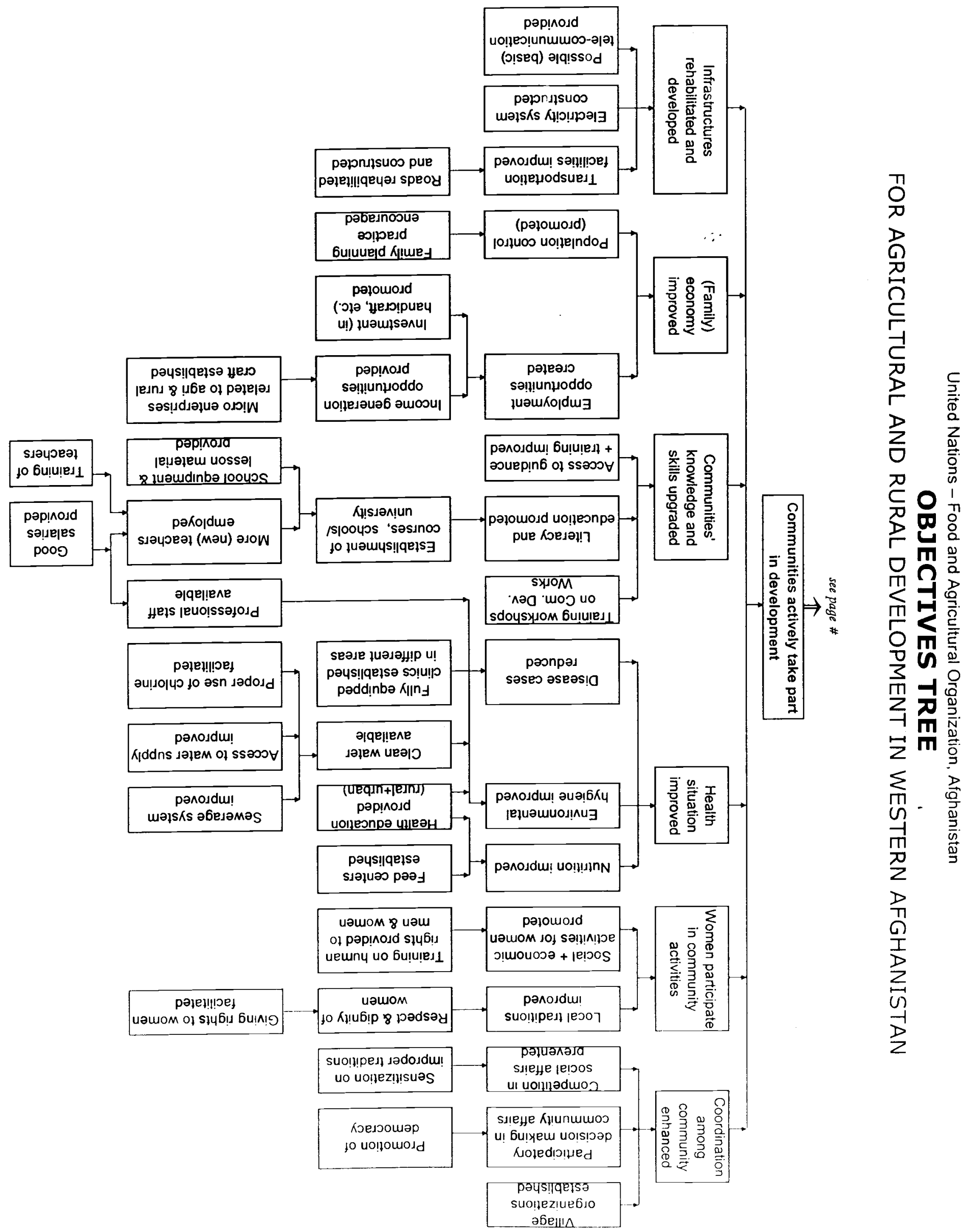




\section{Stakeholders Analysis}

The wide-ranging intervention requirements concluded by the Objectives Analysis highlighted the need to swot up various stakeholders.

Analyse the strengths/potential and role/obligation of all individuals, groups and organizations connected with the objectives. The information generated in this analysis will help in deciding the future partnerships and involvement of wider group and its strengths to benefit implementation.

Through brainstorming on cards, workshop participants suggested various involved parties to the strategy. These were later categorized into the following five categories:

- Government organizations

- Community

- Private Sector

- UN Agencies

- NGOs (both local and international) and Donors

Equal number of sub-groups were constituted to carryout rudimentary study of each stakeholder.

$$
\text { Day } 4
$$

Fourth day of the workshop began with the group work session where the participants deliberated on various stakeholders and their strengths and anticipated role towards the strategy. The group faced difficulties in specifying the strengths/potential in particular; also, obstacles were met in stating details about others - like private sector, NGOs, etc. was observed.

The results of the group-work were presented to the plenary, in due course, adjustments suggested by the participants were accommodated into the final product.

Afterwards, the workshop participants were invited to discuss the issue of "ownership" of the strategy; i.e., who takes the responsibility of pursuing it (with the Government and the donors), as well as to seek and acquire support and take charge to realize it.

Participants were of the view that no single organization can shoulder the responsibility and suggested that key s takeholders from Government, Community and UN organizations should assume responsibility of the strategy.

Consensus was reached on the following group of stakeholders to equally share the onus.

\begin{tabular}{|l|l|l|}
\hline Government & Community & UN Organizations \\
\hline $\begin{array}{l}\text { - Agriculture \& Animal Husbandry } \\
\text { Department }\end{array}$ & $\begin{array}{l}\text { Village Shuras / } \\
\text { Village } \\
\text { - Rural Rehabilitation Department (RRD) } \\
\text { - Irrigation Department }\end{array}$ & $\begin{array}{l}\text { Organizations } \\
\text { UNAMA }\end{array}$ \\
\hline
\end{tabular}

Following pages present the output of this brief analysis 


\section{United Nations - Food \& Agricultural Organization, Afghanistan \\ STAKEHOLDER ANALYSIS \\ FOR AGRICULTURAL \& RURAL DEVELOPMENT IN \\ WESTERN AFGHANISTAN \\ (Herat, Farah, Ghor \& Badghiz Provinces)}

\section{GOVERNMENT}

\begin{tabular}{|c|c|c|}
\hline Stakeholder & Strengths/ Potential & $\begin{array}{l}\text { Role/ Obligation towards this } \\
\text { Strategy }\end{array}$ \\
\hline $\begin{array}{l}\text { Agriculture Department * } \\
\text { - Improved Seed Enterprise } \\
\text { (ISE) } \\
\text { - Extension Section } \\
\text { - Livestock Section } \\
\text { - Chemical Fertilizer \& Agri. } \\
\text { - Services Section } \\
\text { - Farm Management Section } \\
\text { - Cooperatives Section } \\
\text { - } \text { Agri. Mechanization Section } \\
\text { - Pesearch Section Section } \\
\text { - Forestry Section } \\
\text { - Veterinary Section }\end{array}$ & $\begin{array}{l}\text { - Field offices } \\
\text { - Manpower } \\
\text { - Know-how } \\
\text { - Experience }\end{array}$ & $\begin{array}{l}\text { - To increase agriculture production } \\
\text { - Coordination of all Agri- projects, } \\
\text { programs and organizations } \\
\text { - Quality control } \\
\text { - Design and delivering of courses }\end{array}$ \\
\hline $\begin{array}{l}\text { Irrigation Department* } \\
\text { - Hydro-Metrology Section }\end{array}$ & $\begin{array}{l}\text { - Offices } \\
\text { - Engineers \& technician }\end{array}$ & $\begin{array}{l}\text { - Management of water } \\
\text { - Operation \& maintenance of } \\
\text { irrigation infrastructure. }\end{array}$ \\
\hline RRD * & $\begin{array}{l}\text { - Data about rural areas } \\
\text { - Equipment } \\
\text { - Manpower } \\
\text { - Budget (lot of money) }\end{array}$ & $\begin{array}{l}\text { - Rural rehabilitation and development } \\
\text { - Assessment of needs, problems } \\
\text { - Socials organization } \\
\text { - Encourage peoples' participation }\end{array}$ \\
\hline Transportation Department & - Sub-offices and trucks & - Management of transport facility \\
\hline Agriculture Bank & - Money & $\begin{array}{l}\text { - Banking facility to farmers e.g. } \\
\text { credit }\end{array}$ \\
\hline Planning Department & $\begin{array}{l}\text { - Technical manpower } \\
\text { - Planning strategy }\end{array}$ & $\begin{array}{l}\text { - Integration of strategy into planning } \\
\text { - Collection and provision of data } \\
\text { - Monitoring of development plans. } \\
\text { - Coordination }\end{array}$ \\
\hline $\begin{array}{l}\text { Education Department } \\
\text { - Agriculture Schools } \\
\text { - University }\end{array}$ & $\begin{array}{l}\text { - Existing schools } \\
\text { - Teachers }\end{array}$ & $\begin{array}{l}\text { - Provide basic education } \\
\text { - Provide training and research work } \\
\text { facilities. }\end{array}$ \\
\hline Finance Department & - Availability of money & $\begin{array}{l}\text { - Budget allocation to prioritized plans } \\
\text { (from the strategy) }\end{array}$ \\
\hline
\end{tabular}


FOR AGRICULTURAL \& RURAL DEVELOPMENT IN WESTERN AFGHANISTAN

(Herat, Farah, Ghor \& Badghiz Provinces)

\section{GOVERNMENT}

\begin{tabular}{|c|c|c|}
\hline Stakeholder & Strengths/ Potential & $\begin{array}{l}\text { Role/ Obligation towards this } \\
\text { Strategy }\end{array}$ \\
\hline Women Affairs Department & - Women improvement & $\begin{array}{l}\text { - Establishment of Shuras for women } \\
\text { development. } \\
\text { - Promote women participation in } \\
\text { development. } \\
\text { - Develop projects \& provide funds } \\
\text { for women upliftment projects } \\
\end{array}$ \\
\hline Public Health Department & $\begin{array}{l}\text { - Clinics in Villages and } \\
\text { Districts } \\
\text { - Health Centres } \\
\text { - Doctors } \\
\end{array}$ & Establish clinics \& health centres. \\
\hline Public Works Department & $\begin{array}{l}\text { - Engineers (technician) } \\
\text { - Equipments } \\
\text { - Budget } \\
\end{array}$ & $\begin{array}{l}\text { Operation, maintenance and } \\
\text { rehabilitation of access (roads) }\end{array}$ \\
\hline $\begin{array}{l}\text { Chambers of Commerce \& } \\
\text { Industries }\end{array}$ & $\begin{array}{l}\text { - Businessman, } \\
\text { - Regulation of trades, } \\
\text { - Data about markets }+ \\
\text { products }\end{array}$ & $\begin{array}{l}\text { - Provide market information } \\
\text { - Link producers to market (esp. } \\
\text { Export) } \\
\text { - Promote /seek investments } \\
\text { - Provide import - export facilities. }\end{array}$ \\
\hline $\begin{array}{l}\text { Refugees Repatriation } \\
\text { Department }\end{array}$ & $\begin{array}{l}\text { - Offices } \\
\text { - Collaboration with WFP \& } \\
\text { UNHCR } \\
\end{array}$ & - Encourage refugees, IDPs to return \\
\hline Labour Works Department & - Labour laws & $\begin{array}{l}\text { - Awareness of labour rules } \\
\text { - Provide job for (educated) people }\end{array}$ \\
\hline $\begin{array}{l}\text { Communication and } \\
\text { Electricity Department }\end{array}$ & $\begin{array}{l}\text { - Equipments } \\
\text { - Income } \\
\text { - Technicians } \\
\end{array}$ & $\begin{array}{l}\text { - Expand services to whole region. } \\
\text { - Provide power and communication } \\
\text { for projects. }\end{array}$ \\
\hline $\begin{array}{l}\text { District Governors } \\
\text { - Police Department }\end{array}$ & $\begin{array}{l}\text { - Police force } \\
\text { - Collaboration with } \\
\text { (NGOs) and UN agencies }\end{array}$ & $\begin{array}{l}\text { - Provide security, law \& order for the } \\
\text { people } \\
\text { - Improve their abilities \& support } \\
\text { them (development organizations) }\end{array}$ \\
\hline Municipality & $\begin{array}{l}\text { - Technician } \\
\text { - Money } \\
\text { - Markets }\end{array}$ & $\begin{array}{l}\text { - Provide better living condition to } \\
\text { urban population }\end{array}$ \\
\hline
\end{tabular}




\section{United Nations - Food \& Agricultural Organization, Afghanistan \\ STAKEHOLDER ANALYSIS \\ FOR AGRICULTURAL \& RURAL DEVELOPMENT IN \\ WESTERN AFGHANISTAN \\ (Herat, Farah, Ghor \& Badghiz Provinces)}

\section{COMMUNITY}

\begin{tabular}{|c|c|c|}
\hline Stakeholders & \begin{tabular}{|l} 
Strengths/ Potential \\
\end{tabular} & $\begin{array}{l}\text { Role/ Obligation towards this } \\
\text { Strategy }\end{array}$ \\
\hline Farmers & $\begin{array}{l}\text { - Land } \\
\text { - Experience } \\
\text { - Working ability } \\
\text { - Local tools } \\
\text { - Water source } \\
\end{array}$ & $\begin{array}{l}\text { - Adaptability of new techniques/ } \\
\text { technology } \\
\text { - Grow variety of crops } \\
\text { - Participate actively in agriculture } \\
\text { development process }\end{array}$ \\
\hline Livestock Owners & $\begin{array}{l}\text { - Have cattle (animals) } \\
\text { - Pastures } \\
\text { - Experience } \\
\end{array}$ & $\begin{array}{l}\text { - Provide by-products for trade } \\
\text { - Adaptability } \\
\text { - Raise various kinds of animals }\end{array}$ \\
\hline Women & $\begin{array}{l}\text { - Work ability } \\
\text { - Generation builder } \\
\text { - Having enough time }\end{array}$ & $\begin{array}{l}\text { Participate in development } \\
\text { process of the country } \\
\text { - Participate actively in: } \\
\text { - Education } \\
\text { - Health service } \\
\text { - Agriculture production } \\
\text { - Income generation activities }\end{array}$ \\
\hline Skilled Labour & \begin{tabular}{ll|}
- & Knowledge \\
- & Take role in development and \\
rehabilitation
\end{tabular} & $\begin{array}{l}\text { - Can work properly } \\
\text { - Can train unskilled labourers }\end{array}$ \\
\hline $\begin{array}{l}\text { Village Organization, } \\
\text { Village Shura } * \\
\end{array}$ & $\begin{array}{l}\text { - Traditional rule } \\
\text { - Influence on people } \\
\end{array}$ & $\begin{array}{l}\text { - Help in all development process } \\
\text { - Decision making }\end{array}$ \\
\hline Mullahs & $\begin{array}{l}\text { - Respect } \\
\text { - Dignity } \\
\text { - Full of information }\end{array}$ & $\begin{array}{l}\text { - Good motivator } \\
\text { - Important role in consultation and } \\
\text { decision making } \\
\text { - Good monitoring of (dev.) } \\
\text { activity } \\
\end{array}$ \\
\hline Handicapped & $\begin{array}{l}\text { - Energy } \\
\text { - Time } \\
\text { - Abilities } \\
\end{array}$ & $\begin{array}{l}\text { - Can offer social services } \\
\text { - Take part in enterprises } \\
\text { - Can be trainers }\end{array}$ \\
\hline Displaced People (IDPs) & $\begin{array}{l}\text { - Capacity to work } \\
\text { - Professional skills }\end{array}$ & $\begin{array}{l}\text { - Man power } \\
\text { - Achieve technical affairs }\end{array}$ \\
\hline $\begin{array}{l}\text { Water Users Association, } \\
\text { Mirabs }\end{array}$ & $\begin{array}{l}\text { Information about water } \\
\text { management and resources }\end{array}$ & $\begin{array}{l}\text { - Facilitate water supply and } \\
\text { management }\end{array}$ \\
\hline
\end{tabular}


United Nations - Food \& Agricultural Organization, Afghanistan

STAKEHOLDER ANALYSIS

FOR AGRICULTURAL \& RURAL DEVELOPMENT IN

WESTERN AFGHANISTAN

(Herat, Farah, Ghor \& Badghiz Provinces)

\section{COMMUNITY}

\begin{tabular}{|c|c|c|}
\hline Stakeholders & Strengths/ Potential & $\begin{array}{l}\text { Role/ Obligation towards this } \\
\text { Strategy }\end{array}$ \\
\hline Commanders & $\begin{array}{l}\text { - Power } \\
\text { - Population (supporters) }\end{array}$ & $\begin{array}{l}\text { Provide opportunity for } \\
\text { development activity }\end{array}$ \\
\hline Unskilled Labours & $\begin{array}{l}\text { - Emergency supporters } \\
\text { - Time }\end{array}$ & - Offer physical service \\
\hline Returnees (from abroad) & $\begin{array}{l}\text { - } \text { Educated } \\
\text { - Money } \\
\text { - Know foreign markets/needs }\end{array}$ & $\begin{array}{l}\text { - Play key role in social \& } \\
\text { economic development } \\
\text { - Can invest }\end{array}$ \\
\hline
\end{tabular}


(Herat, Farah, Ghor \& Badghiz Provinces)

\section{PRIVATE SECTOR}

\begin{tabular}{|c|c|c|}
\hline Stakeholders & \begin{tabular}{|l|} 
Strengths/ Potential \\
\end{tabular} & Role/ Obligation towards Strategy \\
\hline $\begin{array}{l}\text { Agriculture } \\
\text { Cooperatives }\end{array}$ & $\begin{array}{l}\text { - Possess extensionists } \\
\text { - Ability to provide farms } \\
\text { requirements } \\
\end{array}$ & $\begin{array}{l}\text { - Provide extension to farmers and } \\
\text { farms services }\end{array}$ \\
\hline $\begin{array}{l}\text { Construction } \\
\text { Companies }\end{array}$ & $\begin{array}{l}\text { - Design \& construction experience } \\
\text { - Professionals }\end{array}$ & $\begin{array}{l}\text { - Planning and construction of } \\
\text { projects and services }\end{array}$ \\
\hline Traders & - Trading abilities & $\begin{array}{l}\text { - Traders provide needed materials } \\
\text { and goods } \\
\text { - Promote local produce + products } \\
\text { - Offer good prices (to farmers) }\end{array}$ \\
\hline Industrialists & - Provide products & $\begin{array}{l}\text { - Procurement of elementary } \\
\text { products } \\
\text { - Invest in agriculture related } \\
\text { business, esp. processing \& } \\
\text { packaging. }\end{array}$ \\
\hline Associations & $\begin{array}{l}\text { - Ability to organize community } \\
\text { activities and take participatory } \\
\text { decision }\end{array}$ & $\begin{array}{l}\text { - Organize participatory activities, } \\
\text { - Quality control } \\
\text { - Establish input sale points }\end{array}$ \\
\hline Private Transporters & - Possess transport facilities & $\begin{array}{l}\text { - Provide connections and transport } \\
\text { between villages \& city markets }\end{array}$ \\
\hline Cold Storage Units & $\begin{array}{l}\text { Possess freezers \& conservation } \\
\text { facilities }\end{array}$ & $\begin{array}{l}\text { Storing \& transporting food } \\
\text { products }\end{array}$ \\
\hline Laboratories & $\begin{array}{l}\text { - Have knowledge of diagnosis } \\
\text { - Scientific abilities for improvement } \\
\text { and protection }\end{array}$ & $\begin{array}{l}\text { - Diagnosis of human diseases } \\
\text { - Testing soil, water for } \\
\text { improvement \& protection } \\
\end{array}$ \\
\hline $\begin{array}{l}\text { Markets (wholesale } \\
\text { and retail) }\end{array}$ & $\begin{array}{l}\text { - Contain farmers production } \\
\text { - Stabilize economy }\end{array}$ & $\begin{array}{l}\text { - Provide sustainable revenue to the } \\
\text { farmers }\end{array}$ \\
\hline Middlemen & - Help and support marketing & $\begin{array}{l}\text { - Purchasing products \& sell to } \\
\text { others in the market }\end{array}$ \\
\hline Media & - Broadcasting \& publishing facilities & $\begin{array}{l}\text { - Assist in public awareness } \\
\text { - Provide jobs, marketing, products } \\
\text { information }\end{array}$ \\
\hline $\begin{array}{l}\text { Neighbouring } \\
\text { Countries }\end{array}$ & - Provide miscellaneous help & $\begin{array}{l}\text { Provide credits, experience, } \\
\text { equipments, marketing, training } \\
\text { aids, etc. }\end{array}$ \\
\hline
\end{tabular}


STAKEHOLDER ANALYSIS

\section{FOR AGRICULTURAL \& RURAL DEVELOPMENT IN WESTERN AFGHANISTAN}

(Herat, Farah, Ghor \& Badghiz Provinces)

\section{UNITED NATIONS ORGANIZATIONS}

\begin{tabular}{|c|c|c|}
\hline Stakeholders & Strengths/ Potential & $\begin{array}{l}\text { Role/ Obligation towards this } \\
\text { Strategy -common for all }\end{array}$ \\
\hline 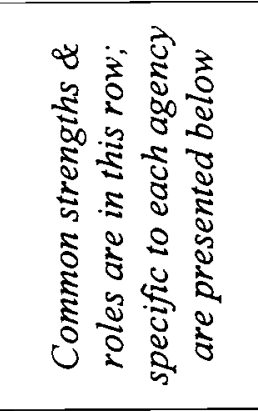 & $\begin{array}{l}\text { - Technical staffs } \\
\text { - Existing field offices } \\
\text { - Facilities/knowledge } \\
\text { - Experience } \\
\text { - Funds } \\
\text { - Established partnerships \& working } \\
\text { relations with local departments and } \\
\text { organizations. }\end{array}$ & \multirow{9}{*}{$\begin{array}{l}\text { - Making project proposals } \\
\text { - Seeking fund } \\
\text { - Implementing project } \\
\text { - Propagate strategy } \\
\text { - Support in institution building } \\
\text { and systems development } \\
\text { - Cross-sector joint working } \\
\text { - Capacity building for Afghan } \\
\text { NGOs and Government } \\
\text { departments }\end{array}$} \\
\hline $\mathrm{FAO}^{*}$ & $\begin{array}{l}\text { - Privatization } \\
\text { - Irrigation } \\
\text { - Food \& Agriculture } \\
\text { - Poverty eradication and community } \\
\text { empowerment (PEACE) } \\
\text { - Capacity building }\end{array}$ & \\
\hline $\begin{array}{l}\text { UN } \\
\text { HABITAT }\end{array}$ & $\begin{array}{l}\text { - Community development } \\
\text { - Municipality }\end{array}$ & \\
\hline$\overline{\text { UNHCR }}$ & $\begin{array}{l}\text { - IDPs, returnees \& refugees support } \\
\text { - Shelter } \\
\text { - Agriculture }\end{array}$ & \\
\hline UNDCP & $\begin{array}{l}\text { - Drug control } \\
\text { - Poppy substitution }\end{array}$ & \\
\hline UN OPS & $\begin{array}{l}\text { - Roads } \\
\text { - School buildings } \\
\text { - Agriculture } \\
\text { - Project operational services }\end{array}$ & \\
\hline WFP & $\begin{array}{l}\text { - Food for work } \\
\text { - Food for education } \\
\text { - Food for related programs }\end{array}$ & \\
\hline $\mathrm{WHO}$ & $\begin{array}{l}\text { - Nutrition program } \\
\text { - Vaccination } \\
\text { - Health related programs }\end{array}$ & \\
\hline UNAMA * & $\begin{array}{l}\text { - Coordination \& security } \\
\text { - Disarmament / de-mobilization } \\
\text { - Human rights }\end{array}$ & \\
\hline
\end{tabular}


United Nations - Food \& Agricultural Organization, Afghanistan

\section{STAKEHOLDER ANALYSIS}

FOR AGRICULTURAL \& RURAL DEVELOPMENT IN WESTERN AFGHANISTAN

(Herat, Farah, Ghor \& Badghiz Provinces)

\section{UNITED NATIONS ORGANIZATIONS}

\begin{tabular}{|c|c|c|}
\hline Stakeholders & Strengths/ Potential & $\begin{array}{l}\text { Role/ Obligation towards this } \\
\text { Strategy-common for all }\end{array}$ \\
\hline UNICEF & $\begin{array}{l}\text { - Health } \\
\text { - Education } \\
\text { - Water \& sanitation } \\
\text { - Mother and child health }(\mathrm{MCH}) \\
\text { - Vaccination }\end{array}$ & \\
\hline$\overline{\mathrm{UN} M A C A}$ & $\begin{array}{l}\text { - Mine awareness } \\
\text { - Mine clearance }\end{array}$ & $\begin{array}{l}\text { - Clearance of residential area, } \\
\text { roads and agriculture lands on } \\
\text { priority }\end{array}$ \\
\hline
\end{tabular}


United Nations - Food \& Agricultural Organization, Afghanistan

STAKEHOLDER ANALYSIS

FOR AGRICULTURAL \& RURAL DEVELOPMENT IN

WESTERN AFGHANISTAN

(Herat, Farah, Ghor \& Badghiz Provinces)

NGOs - DONORS

\begin{tabular}{|c|c|c|c|}
\hline & Stakeholders & Strength/ Potential & $\begin{array}{l}\text { Role/ Obligation towards } \\
\text { Strategy }\end{array}$ \\
\hline \multirow[t]{2}{*}{ 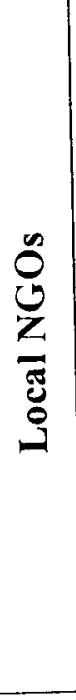 } & \multirow[t]{2}{*}{$\begin{array}{l}\text { - } \text { ARAA } \\
\text { - } \text { RRAA } \\
\text { - } \text { AREA } \\
\text { - } \text { COAR } \\
\text { - ADF } \\
\text { - AHDAA } \\
\text { - } \text { GRCO } \\
\text { - } \text { CHA }\end{array}$} & $\begin{array}{l}\text { - Working in remote area and better } \\
\text { out reach } \\
\text { - Low implementing cost } \\
\text { - Better communication } \\
\text { - More secured } \\
\text { - Knowledge about area } \\
\text { - Knowing cultural system } \\
\text { - Knowing problems } \\
\text { - Fast implementing } \\
\end{array}$ & $\begin{array}{l}\text { Common for local and } \\
\text { international NGOs. } \\
\text { - Making project proposal } \\
\text { - Prioritized working areas } \\
\text { - Provide supervision }\end{array}$ \\
\hline & & 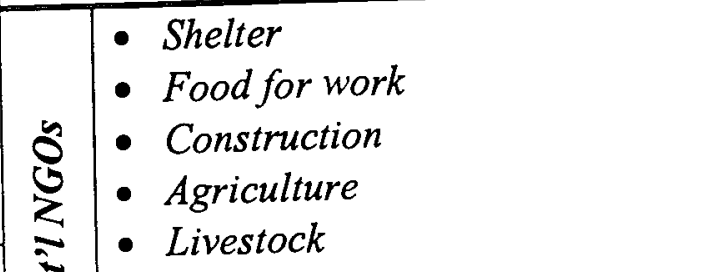 & $\begin{array}{l}\text { - } \text { Provide monitoring } \\
\text { - Reporting } \\
\text { - Provide assessments and } \\
\text { surveys }\end{array}$ \\
\hline \multirow{2}{*}{ 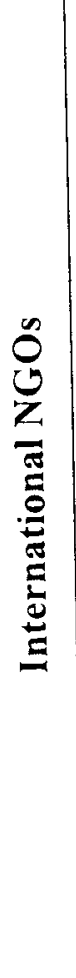 } & \multirow{2}{*}{$\begin{array}{l}\text { - IOM } \\
\text { - } \text { DACAAR } \\
\text { - } \text { ACBAR } \\
\text { - } \text { AFGHAN AID } \\
\text { - } \text { DCA } \\
\text { - ICMC } \\
\text { - IFRC } \\
\text { - IMC } \\
\text { - HELAR } \\
\text { - GAA } \\
\text { - ICRC } \\
\text { - ALISIE } \\
\text { - OI } \\
\text { - } \text { WAR CHILD } \\
\text { - } \text { ACRA } \\
\text { - WORLD VISION }\end{array}$} & 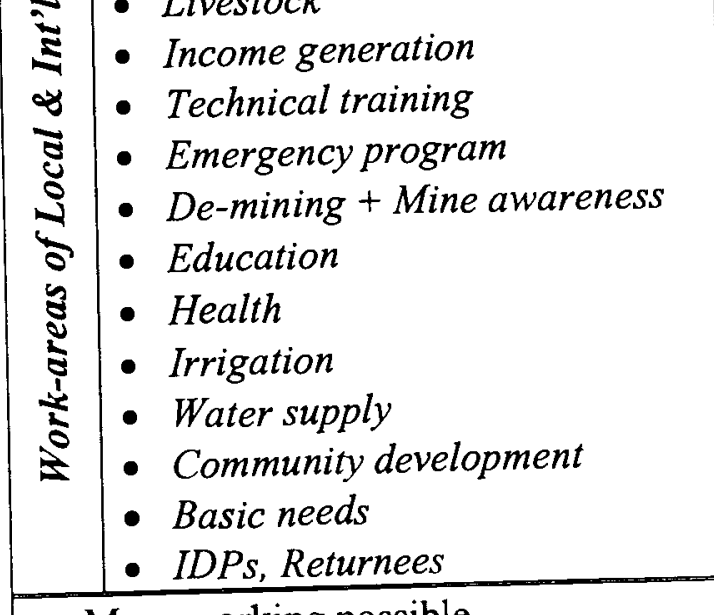 & $\begin{array}{l}\text { surveys } \\
\text { - } \text { Trying to find funds } \\
\text { - Implementing project } \\
\text { - Accountability and } \\
\text { transparency } \\
\text { - Integrate strategy in their } \\
\text { planning }\end{array}$ \\
\hline & & $\begin{array}{l}\text { - More working possible } \\
\text { - } \text { Better relationship with donors/UN } \\
\text { - Ber getting funds } \\
\text { - Familiarity with international } \\
\text { organization } \\
\text { - Worldwide experience } \\
\text { - Better knowledge }\end{array}$ & \\
\hline
\end{tabular}


United Nations - Food \& Agricultural Organization, Afghanistan

STAKEHOLDER ANALYSIS

\section{FOR AGRICULTURAL \& RURAL DEVELOPMENT IN WESTERN AFGHANISTAN}

(Herat, Farah, Ghor \& Badghiz Provinces)

\section{NGOs - DONORS}

\begin{tabular}{|c|c|c|c|}
\hline & Stakeholders & Strength/ Potential & $\begin{array}{l}\text { Role/ Obligation towards } \\
\text { Strategy }\end{array}$ \\
\hline 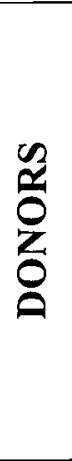 & $\begin{array}{ll}\text { - } & \text { GTZ (Germany) } \\
\text { - } & \text { KfW (Germany) } \\
\text { - } & \text { EU/ECHO } \\
\text { - } & \text { IRC } \\
\text { - } & \text { EO/CA } \\
\text { - } & \text { CRS } \\
\text { - } & \text { BURO Population } \\
& \text { refugees and } \\
& \text { immigration (USA) } \\
\end{array}$ & $\begin{array}{l}\text { - Money } \\
\text { - Supporting development }\end{array}$ & $\begin{array}{l}\text { - To provide funds } \\
\text { - Prioritizing proposal } \\
\text { - Supervision }\end{array}$ \\
\hline
\end{tabular}




\section{Strategy Planning}

The information collected in previous steps, that form part of the analytical part of the ZOPP process, was then utilized in the formulation of the "Strategic Plan".

Since the workshop was charged with the responsibility to develop the strategic framework for the Agriculture and Rural Development, a complete planning matrix (PPM) - with indicators and assumptions was not attempted.

\section{Overall Goal, Programme Purpose and Results}

In a brain storming session at the end of the day four, participants wrote cards for overall goal and programme purpose. Participants were reminded to recollect the objectives analysis, as it contained the ideas for the goal and purpose. Several ideas were presented by the group, these ranged from increased income and higher production to ever higher aims like strong economy and stable country, or some too specific, which were utilised for the formulation of programme purpose.

Through facilitated discussions on several options the workshop participants agreed on the following overall goal and purpose:

\section{LIVING STANDARDS OF THE PEOPLE IN WESTERN AFGHANISTAN IMPROVED}

The agreed upon programme purpose reads:

\section{PRODUCTION SYSTEMS IMPROVED AND SUSTAINABLY MANAGED}

Later, owing to moderated discussions, the group improved the statements of the major objectives (objectives tree) to arrive at following six results:

1) Agriculture productivity increased.

2) Irrigation system rehabilitated and water resource management improved.

3) Animal production increased and animal husbandry improved.

4) Coverage of forest area enhanced and properly managed

5) Communities actively participate in development.

6) Institutions are efficiently functioning for development and rehabilitation.

\section{Major Activities}

The last day of the workshop started with the re-cap of the objectives and then the task of activity formulation for all the results was executed by sub-groups. For this purpose, the groups pulled out the key elements from the objectives tree, also, during the exercise, analogous elements were combined in comprehensive activities.

Later, the results of the group work were reviewed jointly by the workshop participants. During this review activities which in the participant's opinion were expedient for the achievement of the result were added.

The next four pages present the strategic plan prepared by the workshop participants. 


\section{FOR AGRICULTURAL \& RURAL DEVELOPMENT IN WESTERN AFGHANISTAN \\ (Herat, Farah, Ghor \& Badghiz Provinces)}

\section{Summary of Objectives \& Activities}

$\begin{array}{lc}\text { Overall Goal } & \text { LIVING STANDARDS OF THE PEOPLE IN } \\ \text { WESTERN AFGHANISTAN IMPROVED. } \\ \text { Programme Purpose } & \text { PRODUCTION SYSTEMS IMPROVED AND } \\ & \text { SUSTAINABLY MANAGED. }\end{array}$

\section{Result 1}

\section{AGRICULTURE PRODUCTIVITY INCREASED}

\section{Major Activities}

1

1.1. Update agriculture policy and facilitate in implementation.

1.2. Introduce and promote agriculture zonalization*

1.3. Improvement and strengthening of extension services for transfer of new techniques to farmers.

1.4. Improvement + strengthening of capacities of technical and extension staffs.

1.5. Production, multiplication and distribution of improved seeds of cereal, cash, vegetable and industrial crops.

1.6. Collection, conservation and utilization of germ-plasm.

1.7. Promotion of mechanization of farming system.

1.8. Establishment of windbreaks.

1.9. Improvement of soil management practices.

1.10. Rehabilitation of drainage system.

1.11. Establishment of fruit tree nurseries.

1.12. Establishment of new orchards.

1.13. Introduce + promote effective orchards management -pruning, trimming, budding, grafting, etc.

1.14. Promotion of integrated pest management (IPM).

1.15. Establishment of agro-support (inputs) system in private sector (employment generation for landless).

1.16. Establishment of credit system for farmers.

1.17. Establishment (and promotion) of processing and packaging facilities for agriculture product especially for dried fruit and fresh vegetables.

1.18. Establishment of cold storage facilities.

1.19. Establishment of agriculture associations.

1.20. Establishment of wholesale market for agriculture products' export.

1.21. Introduce cash crop for replacement of poppy crop.

1.22. Conduct, research and release new varieties.

1.23. Establish and promote enterprises 


\section{United Nations - Food \& Agricultural Organization, Afghanistan STRATEGIC PLAN \\ FOR AGRICULTURAL \& RURAL DEVELOPMENT IN WESTERN AFGHANISTAN

\author{
(Herat, Farah, Ghor \& Badghiz Provinces)
}

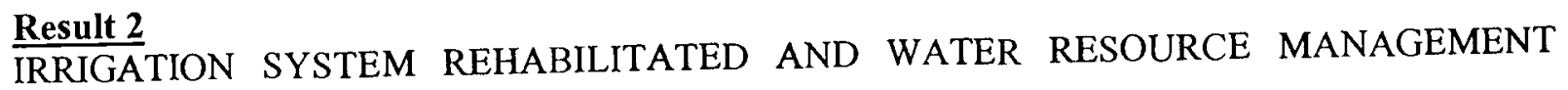 IMPROVED}

\section{Major Activities}

2.1 Institutional restructuring and capacity building within official structure for better irrigation policy and planning.

2.2 Legislation and monitoring of drilling of (deep) wells.

2.3 Establishing technical institute and hire international expatriates to develop national professionals.

2.4 Establishment of Hydro-metrology records and data management system.

2.5 Awareness of and extension to farmers with training and scholarship to national professional.

2.6 Establishment of WUA's and encouraging of investment of private sector.

2.7 Introduction of modern irrigation system \& equipment.

2.8 Land protection.

2.9 Establishment of river training structures.

2.10 Construction of cross-drainage structures.

2.11 Watershed management.

2.12 Rehabilitation of canals and Karezes.

2.13 Construction of diversion dams.

2.14 Construction of hydraulic structure for control of floods.

2.15 Construction of big dams and water reservoirs.

2.16 Protection works.

2.17 Water harvesting.

\section{$\underline{\text { Result } 3}$}

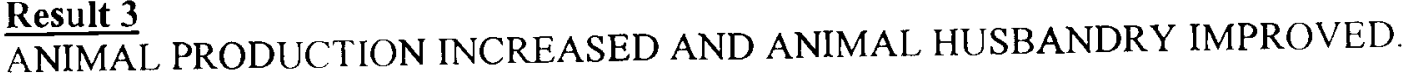

\section{Major Activities}

3.1 Laws and regulation for promotion and protection of livestock industry.

3.2 Training of veterinary staffs in technical + extension practices.

3.3 Establishment of veterinary vaccine production unit.

3.4 Establishment of distribution (sale point) net work for veterinary vaccines, medicine and feed.

3.5 Training of farmers - livestock keepers in better animal husbandry practices.

3.6 Introduction of improved variety mother stock. 


\section{United Nations - Food \& Agricultural Organization, Afghanistan \\ EVALUAITON OF THE WORKSHOP \\ FOR AGRICULTURAL \& RURAL DEVELOPMENT \\ IN WESTERN AFGHANISTAN \\ (Herat, Farah, Ghor \& Badghiz Provinces)}

\section{Critical Remarks}

- All presentations (of the group work) were done by same person, however, other members of the groups should have been asked to present.

- For the designing of such strategic planning 5 days time wasn't enough.

- Leave day (Friday) spent in the workshop.

- Group work was not managed well. According to my idea participants of each group should be replaced as everyone should know and get each others idea better and do the presentations.

- We wasted some of our time during the workshop as sometimes participants came late.

- Limited time and hard work.

- Translation was not good enough.

- The signature of teacher (facilitator) Mahmood was not on the certificate.

- The only negative point was just me because I don't know English.

- The different activities and ideas which were discussed in the workshop should be explained locally and practically for the people in the fields.

- Translation was weak, as some of us came from Ghor, Farah and Badghis provinces. We don't know about the basic grammar of Dari, it was our negative point.

- The groups should be made according the profession. Group members should change during analysis

\section{Complimentary Remarks}

- Found new ideas in the workshop.

- I am familiar with ZOPP.

- The procedure of the workshop was good.

- Good source for increasing the knowledge of participants, sharing of experiences and indirectly beneficial for the population.

- Workshop was participatory; facilitation was excellent; food was good; FAO staff worked hard; and opportunity was provided for everyone to discuss.

- Increased my knowledge about problems and solutions.

- Expect to have more long term workshops.

- First time to participate and found it really interesting.

- All parts of the workshop were useful and enhanced my learning. I liked the program.

- The method of workshop is good.

- What I had expected (from the workshop) is achieved.

- Everything was good.

- We want more such workshops in Heart Province.

- In this workshop 1 learned that collective work is more important.

- The workshop was good because I got good knowledge about our problems.

- We got new ideas from this workshop and learned new techniques.

- We learned a new technical method 


\section{Workshop Evaluation}

The last card writing exercise was the evaluation of workshop. Participants were asked to evaluate the workshop by giving their comments on cards about:

1) What was not good in the workshop and could be avoided next time,

2) What did they like about the workshop?

Critical comments were concerning the language difficulties, time constraint - workload, use of Friday as working day, translation weaknesses and group presentations by same individuals.

In general, the group rated the workshop as excellent as they learned new knowledge, planning techniques and collaborative working. They expressed satisfaction over the facilitation and organizational matters. Many of them requested for more such workshops and hoped that the implementation of the plan will start soon.

Feedback given by the workshop participants is presented on the following pages.

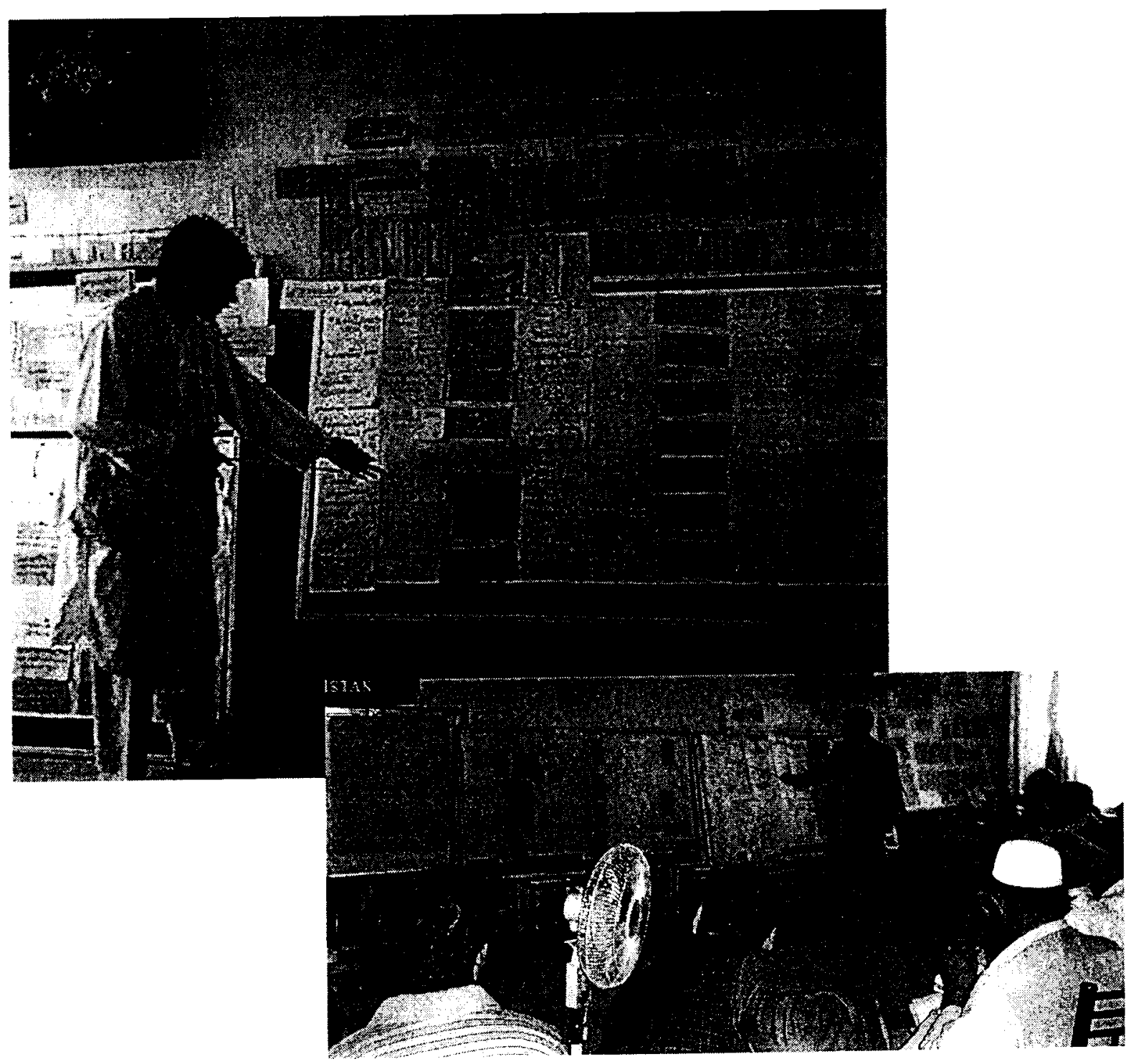




\title{
United Nations - Food \& Agricultural Organization, Afghanistan EVALUAITON OF THE WORKSHOP FOR AGRICULTURAL \& RURAL DEVELOPMENT IN WESTERN AFGHANISTAN
}

\author{
(Herat, Farah, Ghor \& Badghiz Provinces)
}

- First we thank Mr. Mahmood (facilitator). The workshop was very useful and it will help us in our projects in different areas in the future.

- The infrastructure of Afghanistan is destroyed, Conducting such courses/workshops help in capacity building of the people of Afghanistan.

- In my own opinion the workshop was held in very excellent manner and also we wish that in future again participate in workshop like this, one (workshop) is not enough. We need to have more workshops like this, it will be very useful for all of Afghan people.

- I thank Mr. Mahmood, because he repeated (explained) many times and I learned more from his speeches.

- Thanks a lot to Mr. Mahmood, he gave opportunity to us to (discuss) the future. This training was very useful for us and we can use it for future projects as much as possible.

- The way of explaining by Mr. Mahmood was good. The workshop has helped us in the planning. If the Private Pistaleq Farms are constructed, it would be better for future of area and people.

- We had expectations from the workshop regarding forests and its is solved (addressed). So, we want to have practical actions.

- It was a very good workshop and all the issues are solved after uniting the ideas.

- The workshop was very useful. Time was enough for saying the idea. Teaching rule (role) was good. There was no negative point. These workshops should continue.

- We had expectations from the workshop to learn about improving RRD and agriculture and it is solved (addressed).

- We thank from all participants, especially to Mr. Mahmood, because many kinds of problems were revealed and solved (addressed).

- Workshop was very useful, all the issues which we expected (expressed) from the first day are solved (addressed) by the last day.

- Workshop was good. Teaching (facilitation) was good. Participation was good. Hotel also good.

- The problems regarding irrigation were discussed and addressed in the workshop. We hope to have practical activities (implementation) in the near future.

- We the participants from Ghor Province are glad to participate in such a good workshop. It was really regarding (for) the benefits (improvements) of the farmers. We thank from all participants FAO and teacher (facilitator).

- Workshop was very good and very useful. I am very happy to have participated in the workshop and learned something about agriculture and irrigation. I hope to use it in development of Afghanistan.

- Workshop programme was very useful for us. Thanks for considering the community development. The group discussions were good and also agree on the criteria (details) of the works plan in western region.

- This workshop was too good. I found and understood more knowledge and useful things, thanks. 


\section{United Nations - Food \& Agricultural Organization, Afghanistan STRATEGIC PLAN \\ FOR AGRICULTURAL \& RURAL DEVELOPMENT IN WESTERN AFGHANISTAN \\ (Herat, Farah, Ghor \& Badghiz Provinces)}

3.7 Promotion of A.I. for breed improvement.

3.8 Establishment of animal concentrated feed production unit.

3.9 Promotion of fodder corps production project.

3.10 Establishment of veterinary diagnostic laboratories in each province.

3.11 Establishment of community based sustainable veterinary clinics (provision of equipment with instrument and medicines) in each district.

3.12 Establishment of fully equipped quarantines at Tourghondi, Islam Qala and Mile-73 border crossing point with Iran and Turkmenistan.

3.13 Supporting and improving "Karakul" sheep production industries.

3.14 Promotion of dairy and dairy-product marketing.

3.15 Promotion of effective range management.

3.16 Establishment and rehabilitation of water facilities around/ in grazing areas.

3.17 Promotion of poultry, cattle, sheep, goat, bee-keeping, silk worm, fish farming.

3.18 Establishment of credit for farmers.

3.19 Development of extension materials and promotion to farmers through media.

3.20 Promotion and support for animal by-products' processing projects (skins, intestine, wool,

3.21 Promotion and marketing of livestock product for export.

3.22 Organization and empowerment of farmer cooperatives.

\section{Result 4}

COVERAGE OF FOREST AREA ENHANCED \& PROPERLY MANAGED.

\section{Major Activities}

4.1 Establishment of forest policy and strategy.

4.2 Development of systems and capacities for proper management of forests.

4.3 Training and capacity building of staff in relevant technical areas.

4.4 Awareness raising for sustainable use of forests.

4.5 Introduction and promotion of substitute (of wood) energy and construction materials.

4.6 Control of grazing and pasture rehabilitation.

4.7 Promotion of Agro-Silvia pasture.

4.8 Regulation and improvement of timber harvesting and trade.

4.9 Protection and rehabilitation of Pistaleq farms (pistachio forest)

4.10 Plantation of new lands - afforestations.

4.11 Allocation of new place for Kochis and people living in the forests. 


\section{United Nations - Food \& Agricultural Organization, Afghanistan}

\section{STRATEGIC PLAN}

\section{FOR AGRICULTURAL \& RURAL DEVELOPMENT IN WESTERN AFGHANISTAN \\ (Herat, Farah, Ghor \& Badghiz Provinces)}

\section{Result 5 \\ COMMUNITIES ACTIVELY PARTICIPATE IN DEVELOPMENT.}

\section{Major Activities}

5.1 Organization and empowerment of communities.

5.2 Training of change agent from within the community, e.g. Mulla and elders.

5.3 Enhance the awareness on human rights, health education, family planning, etc.

5.4 Establishment of training centre for literacy of man and woman (adult literacy).

5.5 Establishment of small and micro enterprises for locally available raw materials.

5.6 Promotion of income generation activities for women, e.g. tailoring carpet weaving, embroidery, etc.

5.7 Establishment of (drinking) water supply and sanitation systems.

5.8 Rehabilitation and construction of roads to connect villages and cities (markets).

5.9 Rehabilitation and reconstruction of schools in remote areas.

5.10 Provision of teaching materials.

5.11 Establishment of new clinics and provision of equipment, medicines, etc. for existing clinics.

5.12 Establishment of (nutrition program) feeding centres.

5.13 Facilitate in participatory planning, designing and implementation of model development projects by communities.

Result 6

INSTITUTIONS ARE EFFICIENTLY FUNCTIONING FOR DEVELOPMENT AND REHABILITATION.

\section{Major Activities}

6.1 Formulation of development policies and plans.

6.2 Provision of necessary office equipment, accommodation, etc.

6.3 Development and fictionalization of systems for effective functioning, such as, planning, monitoring + evaluation, personnel management, information management, communication, accountability and financial management.

6.4 Capacity building of staffs through training courses, workshops and fellowships.

6.5 Create awareness about work ethics and promote service orientation.

6.6 Improve and update job descriptions.

6.7 Establish a unit for audit of institutions - institutional monitoring and accountability

6.8 Improve coordination among all related organizations 


\section{Workshop Closing \& Adjournment}

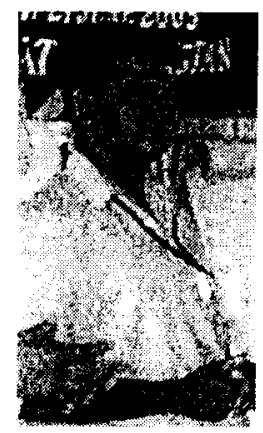

FAO Area Manager, Mr. Rajendra Aryal welcomed the Deputy Governor and extended the a ppreciations to the participants for their i nvaluable efforts and congratulated them for successfully achieving the objectives of the workshop.

The Deputy Governor, Mr. Haji Mir applauded the efforts of the UN FAO for taking steps for the advancement of the country. He expressed $h$ is pleasure over the workshop and its outcomes; and, requested for more such workshop to build the capacities of the locals to enable them improve their own and institutional working.

He mentioned that $70 \%$ of the country's population are farmers and they depend on agriculture for survival. He urged that priority be given to improvement of the sector by expediting the rehabilitation of the damaged infrastructure and systems, in particular, mechanization and forest rehabilitation and protection needs immediate attention. The 23 years of war and the recent drought has badly affected the lands and farmers, it has

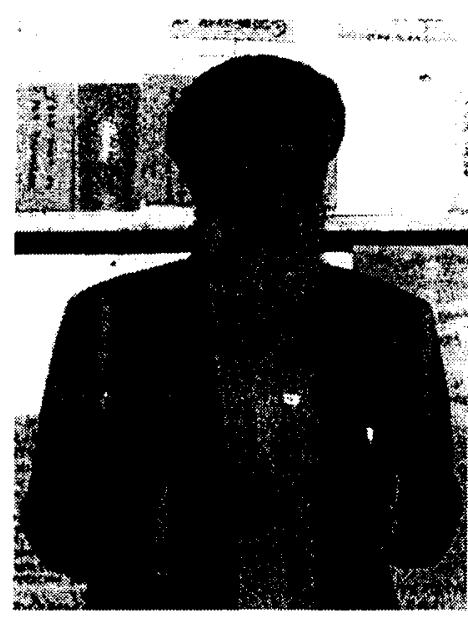
deteriorated the production levels and the farmers have lost the market share. On the other hand, this year's extreme cold weather has doubled the negative effects on the fruit production.

The Deputy Governor called for assistance from the international community to support the settlement of Kochis who live in the Pistaleq Forests. At present this is not only creating forestry related problems but also the local (settled) population is facing troubles. He mentioned that Government alone can not handle the problem, as provision of shelter, water and other necessities are needed for removal of the Kochis from the forests.

He appreciated the strategy prepared by the group as it has comprehensively addressed all the problems. The planning is done, now we are looking forward to some practical activities and hope that the development organizations will improve the infrastructure, especially, irrigation system; this will greatly contribute to improving the living conditions of the people.

In the end, the Deputy Governor, thanked the facilitator and FAO for organizing the workshop.

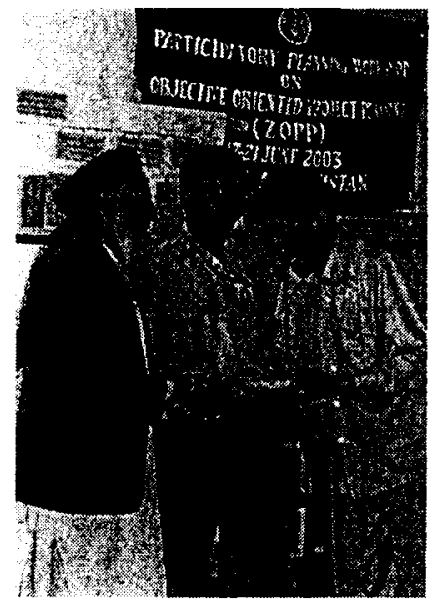

The workshop was then adjourned with best Later, certificates were awarded to the workshop participant by the Deputy Governor, the President of Agriculture Department of Heart and the facilitator.
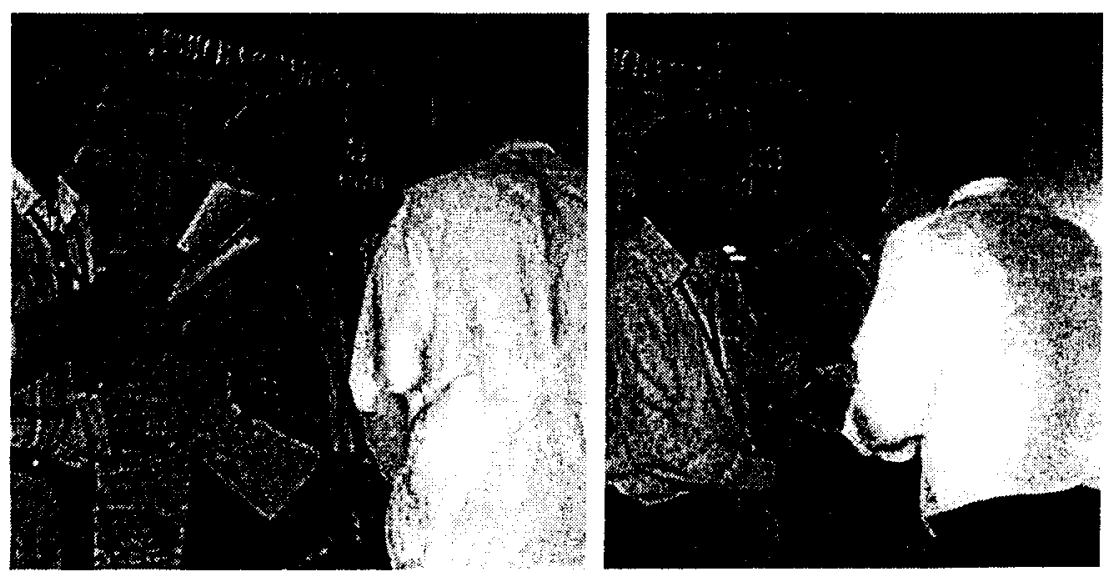

wishes for the implementation of the plan prepared and safe return of the delegates.

FAO - MAAH Joint Strategy Development Workshop

Hemani: $17^{\text {th }}-21^{\text {st }}$ June 2003 , Herat 


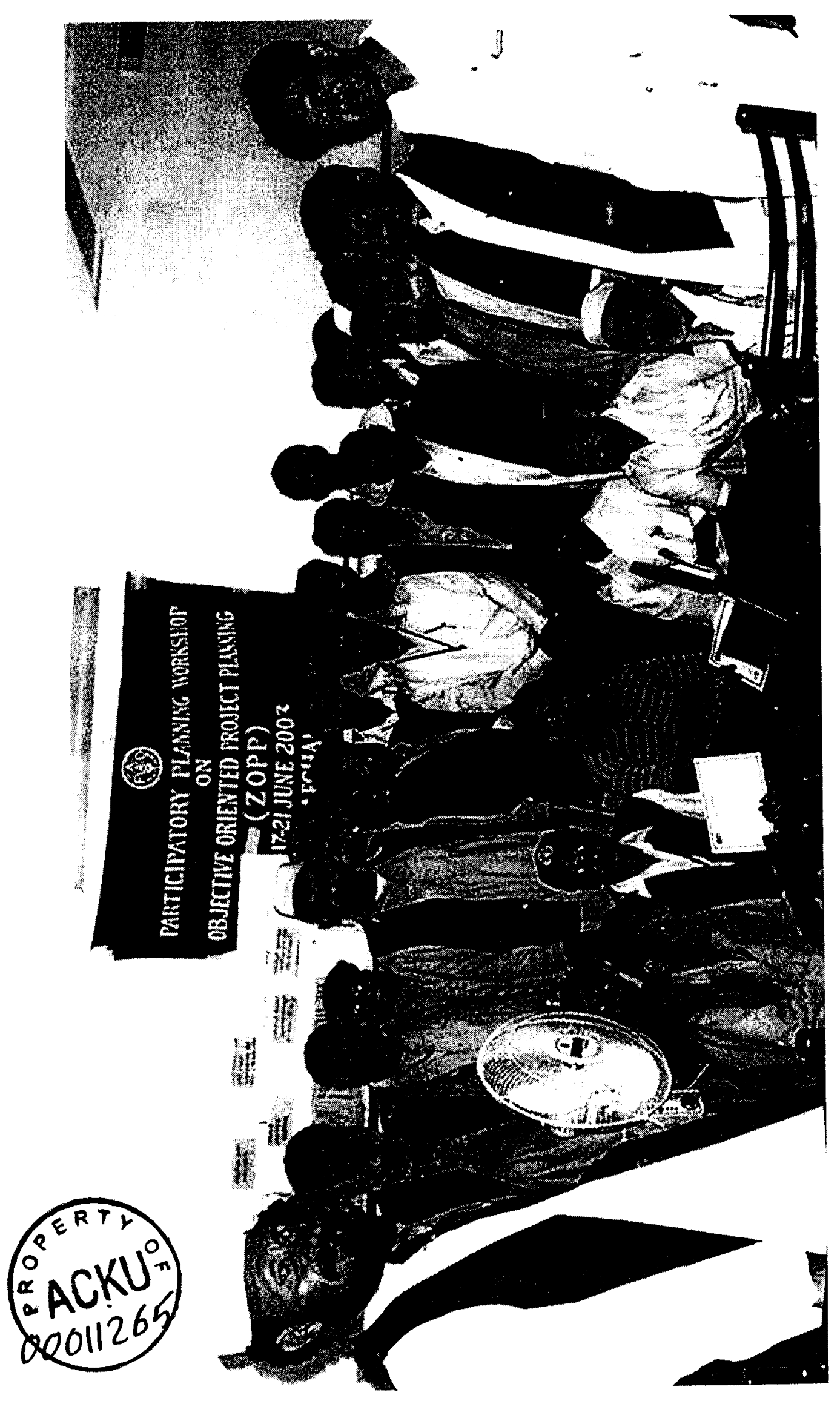

FAO - MAAH Joint Strategy Development Workshop

Hemani: $17^{\text {th }}-21^{\text {st }}$ June 2003, Herat 